\title{
UN DIAGNÓSTICO CONSTITUCIONAL DE LA RECIENTE JURISPRUDENCIA DEL TRIBUNAL SUPREMO ESPAÑOL SOBRE LAS DONACIONES EN RÉGIMEN MATRIMONIAL
}

\section{A Constitutional diagnosis of the recent jurisprudence of the Spanish Supreme Court on donations in marital community property}

\author{
BEATRIZ VILA RAMOS \\ Universidad Francisco de Vitoria \\ b.vila.prof@ufv.es
}

Cómo citar/Citation

Vila Ramos, B. (2021).

Un diagnóstico constitucional de la reciente jurisprudencia del Tribunal

Supremo español sobre las donaciones en régimen matrimonial. Anuario Iberoamericano de Justicia Constitucional, 25(2), 513-550.

doi: https://doi.org/10.18042/cepc/aijc.25.16

\section{Resumen}

Desde el año 2019 el criterio jurisprudencial de interpretación del derecho de reembolso en las donaciones entre esposos casados en régimen de gananciales se ha visto modificado, siendo admitido por el tribunal que aun cuando el bien mantenga el carácter ganancial, por haberlo manifestado expresamente ambos cónyuges en el momento de la adquisición, si se prueba que el dinero con el que realizó la adquisición procedía de caudal privativo, se reconoce el derecho de reembolso a favor del cónyuge que realizó la aportación, sin que se establezcan plazos y sin requerir haber realizado reserva alguna.

A lo largo del artículo, y desde un enfoque constitucional, se analiza si el criterio seguido por el Tribunal Supremo vulnera el principio de igualdad, los principios básicos del Estado de derecho, o el especial deber que la Constitución establece para los poderes públicos de protección a la familia. 


\section{Palabras clave}

Donación; derecho de reembolso; régimen económico de gananciales; bienes privativos; bienes gananciales; jurisprudencia constitucional; protección a la familia; derecho a la igualdad y discriminación.

\section{Abstract}

Since 2019, the jurisprudential criterion for interpreting the right of reimbursement in donations between spouses married in community of property regime has been modified, with the Court admitting that even when the property maintains its community property character, as both spouses expressly stated at the time of acquisition (this may well be through the donation), if it is proven that the money with which the acquisition was made came from private wealth, the right of reimbursement is recognised in favour of the spouse who made the contribution, without establishing time limits or requiring any reservation to have been made.

Throughout the article and from a constitutional approach, it is analysed whether the criterion followed by the Supreme Court violates the principle of equality, the basic principles of the rule of law, or the special duty that the Constitution establishes for public authorities to protect the family.

\section{Keywords}

Donation; right of reimbursement; marital community property; constitucional law; matrimonial assets; separate property; protection of the family; the right to equality and discrimination. 


\section{SUMARIO}

I. EI ESTADO DE LA CUESTIÓN EN EL ÁMBITO CONSTITUCIONAL. ANÁLISIS DE LA JURISPRUDENCIA DEL TRIBUNAL CONSTITUCIONAL. II. ALGUNAS CONSIDERACIONES PREVIAS EN TORNO A LA DONACIÓN: 1. Distinción entre los actos de liberalidades de uso y las donaciones. La donación. 2. Distinción entre la donación de bien muebley bien inmueble. III. LASDONACIONES ENTRE ESPOSOS: 1. Breve análisis histórico de la donación entre esposos. 2. Elementos de la donación entre esposos. IV. CLÁUSULAS DE REVERSIÓN Y EL DERECHO DE REEMBOLSO EN LA DONACIÓN, A LA LUZ DE LA JURISPRUDENCIA RECIENTE DEL TRIBUNAL SUPREMO. ESPECIALES CIRCUNSTANCIAS ENTRE LOS CÓNYUGES EN FUNCIÓN DEL RÉGIMEN ECONÓMICO: 1. La donación entre cónyuges y los regímenes económicos matrimoniales. 2. Derecho de reembolso en la donación entre esposos en régimen de gananciales, a la luz de la reciente jurisprudencia del Tribunal Supremo. V. ANÁLISIS DESDE EL ENFOQUE CONSTITUCIONAL DE LA JURISPRUDENCIA DEL TRIBUNAL SUPREMO EN LAS DONACIONES ENTRE ESPOSOS CON RÉGIMEN ECONÓMICO DE GANANCIALES: 1. El principio de igualdad y la prohibición de discriminación a la luz de la jurisprudencia del Tribunal Constitucional. 2. ¿̇Existe a la luz de la jurisprudencia del Tribunal Supremo un tratamiento que falta al principio de igual en las donaciones entre esposos casados en régimen de gananciales? VI. CONCLUSIONES. BIBLIOGRAFíA.

\section{EL ESTADO DE LA CUESTIÓN EN EL ÁMBITO CONSTITUCIONAL. ANÁLISIS DE LA JURISPRUDENCIA DEL TRIBUNAL CONSTITUCIONAL}

Resulta una evidencia para todos aquellos que nos consideramos estudiosos del derecho público, y más si cabe del derecho constitucional, que la Constitución es la base de todo el ordenamiento jurídico, norma fundamental con contenido axiológico y organizativo que, como «norma normarum», incide tanto en el derecho público como en derecho privado. Ahora bien, la especialización propia de cada área jurídica parece a veces obviar ese enfoque y, especialmente en los temas que tratan el derecho civil, algunos olvidan que la Constitución, como primera lex, puede limitar las posibilidades contractuales y de cualquier otro tipo dentro de las relaciones civiles. Nuestro propósito en este artículo es analizar la reciente jurisprudencia del Tribunal Supremo sobre las donaciones entre esposos vinculando la jurisprudencia del Tribunal Constitucional y los criterios consolidados en el ámbito del derecho civil relativo a las donaciones. 
En primer lugar analizaremos las sentencias dictadas por el Tribunal Constitucional que traten el tema de la donación, la especial protección a la familia (art. $39 \mathrm{CE}$ ), el matrimonio (art. $32 \mathrm{CE}$ ) o la discriminación en razón de matrimonio (art. $14 \mathrm{CE}$ ), y ello desde las dos perspectivas desde las que el Tribunal Constitucional ha abordado el estudio de estas cuestiones, bien por su vinculación a la liquidación tributaria, bien a conflictos de competencia entre el Estado y las CC. AA. sobre el desarrollo legislativo del derecho civil.

Respecto al primero de los enfoques, es la Sentencia 209/1988, de 10 de noviembre, la primera que dicta el Tribunal Constitucional analizando la posible discriminación en razón de matrimonio en la liquidación del IRPF. La sentencia analiza la pretensión del actor que solicita, a través de la interposición de recurso de amparo, realizar la declaración de la renta aún casado, independientemente de su esposa. En aquel momento la normativa obligaba a la declaración conjunta de los cónyuges al entender que, al contraer matrimonio, ambos constituían una única unidad contribuyente; la legislación presumía iuris et de iure que el incremento de capacidad económica a resultas del matrimonio era exactamente igual al determinado por la suma de las rentas de uno y otro, aplicando la tarifa progresiva. El tribunal resolvió a favor del actor el recurso entendiendo que la "capacidad económica del contribuyente no queda alterada jurídicamente en razón del matrimonio", pues "gravar con tarifas más elevadas las rentas de dos contribuyentes que no han alterado ni su personalidad ni su capacidad económica sobre la base de una pretendida acumulación, es una discriminación del art. $14 \mathrm{CE}$ », que ni es objetiva ni debida ni guarda la razonable proporcionalidad (STC 75/1983 FJ2).

A resultas de la Sentencia 209/1988, el Tribunal Constitucional resuelve la autocuestión de inconstitucionalidad planteada en la STC 45/1989 de 20 de febrero, y no solo ratifica (ahora ya con efectos erga omnes) que la legislación discrimina fiscalmente en razón de matrimonio cuando obliga a los cónyuges a declarar conjuntamente, profundiza también en un interesante análisis sobre las consecuencias sociales de la no determinación de discriminación desde la evolución que se ha producido en España tras la modificación del Código Civil respecto al rol de la mujer y la igualdad entre los cónyuges que proclama el art. $32 \mathrm{CE}$ cuando establece:

Se trata, sobre todo, de establecer la incidencia que el sistema mismo tiene sobre la división de trabajo en el seno del matrimonio y, en particular, sobre el acceso de los cónyuges al mercado de trabajo, es decir, en la práctica, sobre la influencia que el sistema puede ejercer sobre la opción de la mujer entre el trabajo en el hogar o su incorporación al mercado de trabajo, pues partimos del supuesto de que cualquier norma que incida sobre la vida de la familia debe ser respetuosa con la concepción de ésta que alienta en la Constitución, de la que forma parte la igualdad entre los cónyuges. Esa igualdad se verá seguramente alterada cuando la libertad de elección u oficio de uno de los cónyuges se vea condicionada por las consecuencias económicas que, en razón de la norma tributaria, se seguirán de su elección y, aunque 
carecemos de estudios sociológicos que claramente lo establezcan, parece poco dudoso que el sistema de acumulación de rentas, en cuanto que incrementa la carga tributaria de la familia, desestimula, por decir lo menos, el trabajo fuera del hogar del posible perceptor de la segunda renta que es, en la mayor parte de los casos, la esposa. El uso que de la acumulación de rentas se ha hecho en otros países con la finalidad expresa de «devolver la mujer al hogar» avala claramente esta deducción».

Por todo ello admite que el sistema tributario que obliga a realizar a los matrimonios la declaración de la renta conjunta vulnera el derecho a la igualdad sin razón alguna que lo justifique, y por el solo hecho de haber contraído matrimonio, lo que difícilmente se concilia con el art. 39.1 en relación con el 32 (FJ 7) o con la neutralidad del sistema tributario respecto de la situación recíproca de los cónyuges.

En esta línea resulta también interesante el análisis de la Sentencia 45/1989 (donde se acumulan seis recursos de inconstitucionalidad) y cuyo argumentario toma como base las reflexiones de la Sentencia STC 146/1994 de 12 de mayo que resume los cambios producidos en torno al matrimonio:

Nuestro ordenamiento jurídico ha establecido tradicionalmente una regulación restrictiva de los contratos entre cónyuges. En el ámbito del Derecho privado, el antiguo art. 1334 del Código Civil disponía la nulidad de las donaciones entre cónyuges durante el matrimonio; era asimismo cuestionable la celebración de contratos de carácter oneroso; en concreto, el art. 1458 del Código Civil, en su redacción primitiva disponía que el marido y la mujer no podían venderse bienes recíprocamente, sino cuando se hubiese pactado la separación de bienes o cuando hubiera separación judicial de los mismos bienes. En el marco del Derecho privado, además de las modificaciones específicas en materia de donaciones y compraventa entre cónyuges que han afectado a los citados arts. 1.334 y 1.458 del Código, la Reforma de 1981 ha dado nueva redacción al art. 1.323 estableciendo la regla general según la cual «el marido y la mujer podrán transmitirse por cualquier título bienes y derechos y celebrar entre sí toda clase de contratos»; se posibilita de esta manera la celebración de toda clase de contratos entre los cónyuges, únicamente limitada por las normas generales.

En la STC 60/2015, de 18 de marzo, el Tribunal analiza la cuestión de inconstitucionalidad planteada por la sección séptima de la Sala de lo Contencioso-administrativo del Tribunal Supremo sobre la presunta vulneración de los arts. 14, 31.1 y 139.1 de la Constitución, por el art. 12.bis de la Ley de la Comunidad Valenciana 13/1997, de 23 de diciembre, en la que se regula el tramo autonómico del impuesto sobre la renta de las personas físicas y restantes tributos cedidos, en la redacción dada por el art. 16 de la Ley de la Comunidad Valenciana 10/2006, de 26 de diciembre, de medidas fiscales, de gestión administrativa y financiera, y de organización de la Generalitat. Como establece el propio Tribunal: 
La cuestión sometida a nuestra consideración consiste, pues, en determinar si el hecho de que la bonificación controvertida (aplicable a la liquidación de la tributación) se reconozca únicamente a los parientes del grupo I (descendientes y adoptados menores de veintiún años) y del grupo II (descendientes y adoptados mayores de veintiún años, cónyuges, ascendientes y adoptantes), «que tengan su residencia habitual en la Comunitat Valenciana a la fecha del devengo del impuesto», y no así a los parientes de los mismos grupos I y II que residan fuera del territorio de la Comunidad Autónoma, y si esta regulación es contraria a la especial protección a la familia o al derecho de igualdad (arts. 14, 31.1 y 139.1, todos ellos CE).

La norma valenciana reconocía en las donaciones por sucesión mortis causa un beneficio fiscal de exención en la cuota de tributación del 99\% a los residentes de la Comunidad Valenciana, y por ello el Tribunal analiza si el trato normativo diferenciado en razón de residencia en herederos con la misma relación de parentesco con el causante de la herencia tiene «justificación plausible» (STC 96/2002), siendo entonces que:

[...] lo importante no es la existencia misma de una medida diferente en el territorio nacional» (FJ7), sino la existencia o no de una justificación razonable que legitime la medida diferente (SSTC 96/2002, de 25 de abril, FJ 12, y 100/2012, de 8 de mayo, FJ 4), [así como], la proporcionalidad de la medida, entendida como adecuación razonable al fin legítimo constitucionalmente perseguido (SSTC 88/1986, de 1 de julio, FJ 6, y 100/2012, de 8 de mayo, FJ 4).

En un sentido semejante trata las bonificaciones tributarias en la STC 60/2018, de 4 de junio, que resuelve la cuestión de inconstitucionalidad que plantea la Sección Segunda de la Sala de lo Contencioso-Administrativo del Tribunal Superior de Justicia de Castilla-La Mancha respecto a la Ley de Castilla-La Mancha 14/2007, de 20 de diciembre, por la que se amplían las bonificaciones tributarias del impuesto sobre sucesiones y donaciones. El art. 8 de la citada ley establecía una bonificación autonómica del 95\% en la cuota del impuesto sobre sucesiones y donaciones para los sujetos pasivos incluidos en los grupos de parentesco I (descendientes menores de 21 años) y II (descendientes de 21 o más años, cónyuges y ascendientes) previstos en el art. 20.2 a) de la Ley 29/1987, de 18 de diciembre, reguladora de este impuesto. $\mathrm{El}$ art. 9 establecía:

Normas para la aplicación de la bonificación en donaciones. En el caso de transmisiones lucrativas inter vivos, la aplicación de las bonificaciones establecidas en el art. 8 queda sujeta a que el sujeto pasivo tenga su residencia habitual en CastillaLa Mancha y la necesidad de que la transmisión se haya formalizado en escritura pública, debiendo constar el origen y situación de los bienes y derechos transmitidos, así como su correcta y completa identificación fiscal cuando se trate de bienes o derechos no consistentes en dinero o signo que lo represente. 
Ahora bien, de la Ley 17/2005 la bonificación pasaría a la Ley 9/2008, manteniéndose el requisito de que el donatario tuviera residencia habitual en Castilla-La Mancha. La Ley 9/2008 fue derogada por la Ley 8/2013, de 21 de noviembre, de medidas tributarias, en vigor desde el 1 de enero de 2014, que también dispone unas bonificaciones en la cuota para las adquisiciones inter vivos por los sujetos pasivos incluidos en los grupos I y II de parentesco previstos en el art. 20.2 a) de la Ley reguladora del impuesto sobre sucesiones y donaciones, pero eliminando entre los requisitos para su aplicación el de residencia del donatario (art. 18). El Tribunal, con el mismo argumento, declara inconstitucional las diferencias establecidas en la normativa de tributación para CC. AA. diferentes en razón de residencia, tanto para las donaciones de bienes muebles como para los bienes inmuebles en donaciones inter vivos y mortis causa y por ello declara que: «En la STC 60/2018 establecen que «en la STC 52/2018 hemos declarado inconstitucional y nulo el inciso "[e]l sujeto pasivo deberá tener su residencia habitual en Castilla-La Mancha» del artículo 9 a) de la Ley 9/2008, de 4 de diciembre, de Castilla-La Mancha, de medidas en materia de tributos cedidos", por vulnerar los artículos 14 y 31.1 CE»

Como consecuencia de la resolución de los conflictos de competencia, también ha tratado el Tribunal las cuestiones que afectan de un modo u otro a la regulación sobre el matrimonio, al régimen económico matrimonial y al de donaciones. En la Sentencia 21/2012, de 16 febrero (interesante, pues trae a colación sentencias previas como doctrina del Tribunal), se resuelve una cuestión de inconstitucionalidad planteada por el Juzgado de Primera Instancia e Instrucción núm. 1 de Arenys de Mar respecto a la posible vulneración del art. 149.1.6 por el Código de Familia catalán, Ley del Parlamento de Cataluña 9/1998, de 15 de julio, al introducir una innovación procesal que permite la acumulación de la acción de división de la cosa común a la acción de división del matrimonio que no permite la LEC y que tampoco trae causa en la especialidad del régimen económico matrimonial catalán que, a falta de capitulaciones, opta de forma general por el régimen económico de separación de bienes.

$\mathrm{Al}$ respecto señala en el $\mathrm{FJ} 3$ que:

La doctrina constitucional en relación con el art. 149.1.6 CE ha quedado resumida y estructurada en la STC 47/2004, de 25 de marzo, en los siguientes términos: en primer lugar, que la atribución al Estado de la competencia exclusiva sobre legislación procesal responde a la necesidad de salvaguardar la uniformidad de los instrumentos jurisdiccionales [SSTC 71/1982, de 30 de noviembre, FJ 20; 83/1986, de 26 de junio, FJ 2; 173/1998, de 23 de julio, FJ 16 c)]; en segundo lugar, que la competencia asumida por las Comunidades Autónomas al amparo de la salvedad recogida en el art. 149.1.6 CE no les permite, sin más, introducir en su ordenamiento normas procesales por el mero hecho de haber promulgado regulaciones de Derecho sustantivo en el ejercicio de sus competencias, esto es, innovar el ordenamiento procesal en relación con la defensa jurídica de aquellos derechos e intereses que materialmente regulen, lo que equivaldría a vaciar de contenido o privar de 
todo significado a la especificidad con que la materia procesal se contempla en el art. 149.1.6 CE, sino que, como indica la expresión «necesarias especialidades» del citado precepto constitucional, tan sólo pueden introducir aquellas innovaciones procesales que inevitablemente se deduzcan, desde la perspectiva de la defensa judicial, de las reclamaciones jurídicas sustantivas configuradas por la norma autonómica en virtud de las particularidades del Derecho creado por la propia Comunidad Autónoma, o, dicho en otros términos, las singularidades procesales que se permiten a las Comunidades Autónomas han de limitarse a aquéllas que, por la conexión directa con las particularidades del Derecho sustantivo autonómico, vengan requeridas por éstas (SSTC 71/1982, de 30 de noviembre, FJ 20; 83/1986, de 26 de junio, FJ 2; 121/1992, de 28 de septiembre, FJ 4; 127/1999, de 1 de julio, FJ 5), correspondiendo al legislador autonómico o, en su defecto, a quienes asuman la defensa de la ley en su caso impugnada, ofrecer la suficiente justificación sobre la necesidad de alterar las reglas procesales comúnmente aplicables por venir requeridas por las particularidades del Derecho sustantivo autonómico, salvo que del propio examen de la Ley se puedan desprender o inferir esas «necesarias especialidades (STC 127/1999, de 1 de julio, FJ 5) [STC 47/2004, de 25 de marzo, FJ 4; doctrina reiterada en las SSTC 243/2004, de 16 de diciembre, FJ 6, y 135/2006, de 27 de abril, FJ 2 e)].

En esta sentencia queda claro que el derecho especial de Cataluña organiza el régimen económico del matrimonio de forma distinta al derecho común, si bien las acciones procesales para la liquidación del régimen económico matrimonial no quedan afectadas de esa especialidad y declara por lo tanto que la innovación producida vulnera el art. $149 \mathrm{CE}$ sin que se haya aportado la suficiente justificación para ello.

En el año 2013, en la STC 93/2013 de 23 de abril, el Tribunal tiene ocasión de volver a centrarse en cuestiones que afectan a la regulación del matrimonio cuando resuelve el recurso de inconstitucionalidad presentado por 83 diputados respecto a la Ley Foral 6/2000, de 3 de julio, para la igualdad jurídica de las parejas estables. Los recurrentes alegan que la Ley Foral pretende regular una situación no matrimonial como matrimonial y que ello compromete los derechos al libre desarrollo de la personalidad, a la intimidad personal y familiar y a no casarse (arts. 10.1, 18.1 y 32.1 CE), en la medida en que impone determinados efectos jurídicos a personas que no han expresado su deseo de casarse, alegan también la vulneración del art. 149 CE. La finalidad de la Ley Foral 6/2000 queda explicitada en el último párrafo de su exposición de motivos, al afirmar que:

[...] pretende eliminar las discriminaciones que por razón de la condición o circunstancia personal o social de los componentes de la familia [...] perduran en la legislación, y perfeccionar el desarrollo normativo del principio constitucional de protección social, económica y jurídica de la familia, adecuando la normativa a la realidad social de este momento histórico. 
El Tribunal Constitucional, en el FJ 5, establece:

[...] (referido al artículo 32.2 CE) Dicho precepto constitucional dispone que «la ley regulará las formas de matrimonio, la edad y capacidad para contraerlo, los derechos y deberes de los cónyuges, las causas de separación y disolución y sus efectos». De esta suerte, hemos de considerar que, siquiera por relación con el citado precepto constitucional, la competencia estatal ex art. 149.1.8 CE se extiende al sistema matrimonial (requisitos materiales y formales y causas de extinción) y al contenido personal del matrimonio, esto es, el régimen de derechos y deberes de los cónyuges con exclusión del régimen económico matrimonial en los territorios con competencias propias en Derecho civil especial o foral, lo que, por otra parte, coincidiría con lo dispuesto en el art. 13.1 del Código civil.

El objeto del recurso supone abordar la regulación de una realidad social, la de las parejas estables unidas por una relación afectiva que se desarrolla al margen del matrimonio, cuya existencia puede reconocer el ordenamiento jurídico desde diversas perspectivas, pero sin que ello implique, per se, una equiparación con el matrimonio constitucionalmente garantizado.

En este sentido el Tribunal recuerda lo ya expresado en la STC 184/1990, de 15 de noviembre, que, en su FJ 3, establecía

el matrimonio y la convivencia extramatrimonial no son realidades equivalentes. El matrimonio es una institución social garantizada por nuestra norma suprema, y el derecho a contraerlo es un derecho constitucional (art. 32.1), cuyo régimen jurídico corresponde a la ley por mandato constitucional (art. 32.2), mientras que «nada de ello ocurre con la unión de hecho more uxorio, que ni es una institución jurídicamente garantizada ni hay un derecho constitucional expreso a su establecimiento.

Define también en el FJ 8 las uniones de hecho y establece:

Bajo el concepto de unión de hecho se agrupa una diversidad de supuestos de parejas estables que, no obstante su heterogeneidad, comparten ciertas notas comunes que permiten conformar una noción general unitaria. En efecto, la unión de hecho puede caracterizarse, en principio, como una relación estable de convivencia more uxorio, cuyo elemento definitorio común queda cifrado en la voluntad libremente configurada de permanecer al margen del Derecho en cuanto a las consecuencias jurídicas inherentes a la institución matrimonial a que se refiere el art. $32 \mathrm{CE}$.

y continua: «consustancial a esa libertad de decisión, adoptada en el marco de la autonomía privada de los componentes de la pareja, es el poder de gobernarse libremente en la esfera jurídica de ese espacio propio, ordenando por sí mismos su ámbito privado, el conjunto de derechos, facultades y relaciones que ostenten, si bien dentro de ciertos límites impuestos por el orden social, ya que la autonomía privada no es una regla absoluta». Así, el art. 1255 del Código Civil plasma el principio de autonomía de la voluntad en las relaciones contractuales privadas, 
y dispone que los contratantes pueden establecer todos los pactos, cláusulas y condiciones que tengan por conveniente, «siempre que no sean contrarios a las leyes, a la moral, ni al orden público». Considera por ello que «el régimen jurídico que el legislador puede establecer al efecto deberá ser eminentemente dispositivo y no imperativo, so pena de vulnerar la libertad consagrada en el art. 10.1 CE. De manera que únicamente podrán considerarse respetuosos de la libertad personal aquellos efectos jurídicos cuya operatividad se condiciona a su previa asunción por ambos miembros de la pareja».

Así mismo, en la STC 198/2012, de 6 de noviembre (FJ 10), se afirma que:

El derecho a contraer matrimonio, o a no contraerlo, "se limita a asegurar la capacidad de elección, a impedir el mandato o la imposibilidad absoluta, pero no a asegurar a quien la ejercita en un determinado sentido los mismos efectos que se atribuyen a quien lo hace en otro", añadiendo que "pese a la identidad de los sujetos titulares de la libertad, el contenido de la libertad positiva y negativa no (tiene) por qué ser homogéneo, y que el legislador ordinario (puede) atribuir [...] consecuencias a una y a otra manifestación", de manera "que la primera se constituya en un auténtico derecho subjetivo, mientras que la segunda no sea más que una mera libertad jurídica, integrada en el mismo derecho fundamental, y cuyo contenido se ciñe a la posibilidad de optar o a la existencia de una alternativa de acción" (ATC 204/2003, de 16 de junio, FJ 3).

Aunque hay otras sentencias que durante estos años han resuelto conflictos de competencias en temas relativos a tributos y civil, la STC 82/2016 de 28 de abril nos da luz sobre cuestiones conceptuales que afectan fundamentalmente al reparto de competencias y al criterio a seguir en el desarrollo del derecho civil por las CC. AA. El presidente del Gobierno impugna la Ley de la Comunidad Valenciana 10/2007, de 20 de marzo, de régimen económico matrimonial valenciano, por considerar que incurre en un doble motivo de inconstitucionalidad. En primer lugar, uno de naturaleza competencial, derivado del origen de la norma, al invadirse la competencia exclusiva del Estado en materia de legislación civil derivada del art. 149.1.8 CE, desoyendo la doctrina establecida en la STC 121/1992, de 28 de septiembre, que limita el ámbito de la competencia asumible por la Comunidad Valenciana en la materia al «Derecho consuetudinario que, tras la abolición de los Fueros, haya subsistido». El segundo reproche de inconstitucionalidad se dirige contra los arts. 27.2 y 39 de la Ley de régimen económico matrimonial valenciano, que regulan la inscripción en el Registro Civil de determinados actos, que se consideran materia reservada al Estado (art. 149.1.8 CE).

El objeto del recurso, tras el acuerdo de la Comisión Bilateral de Cooperación Administración General del Estado-Generalitat Valenciana de 8 de junio de 2007 (resolución de 8 de junio de 2007, de la Secretaría de Estado de Cooperación Territorial, publicada en el $B O E$ de 21 de junio) queda limitado a 11 preceptos, aunque la norma impugnada fue modificada por la Ley 8/2009, de 4 de noviembre, de la Generalitat, de modificación de la Ley 10/2007, de 20 de 
marzo de régimen económico matrimonial valenciano que deroga los arts. 30, 37, 47, 48 y la disposición transitoria 2 y modifica los arts. 15.2, 17.2, 27.2, 33.1, 39, 42.2 y 46, de la Ley 10/2007, de 20 de marzo.

La cuestión de fondo en el recurso suponía que el Tribunal debía despejar la duda sobre la posibilidad de recuperación de la normativa histórica de la Comunidad Valenciana (en este caso respecto al régimen económico matrimonial valenciano) vinculada a los antiguos fueros, siempre al amparo del Estatuto de Autonomía o no era necesario. En la comprensión de la sentencia, y en lo que se refiere a la vinculación entre el derecho civil y el derecho constitucional, resulta interesante el voto particular del magistrado don Juan Antonio Xiol Ríos, que nos recuerda que:

[...] el Tribunal Constitucional reconoce relevancia al mandato de actualización de derechos históricos en materia de Derecho privado cuando se incorpora a un Estatuto de Autonomía, entendiendo que dicho reconocimiento, por operar en el campo del Derecho privado, no se opone a la limitación geográfica impuesta por la disposición adicional primera de la Constitución, mientras que, en el campo del Derecho público, la única referencia válida a los derechos históricos es la que deriva del reconocimiento de una vía especial de acceso a la autonomía al amparo de la disposición transitoria segunda de la Constitución.

si bien, como reconoce el magistrado «el criterio de un desarrollo limitado del Derecho foral o especial —emparentado con la que he llamado concepción residual - se mantiene en la argumentación desarrollada por la opinión mayoritaria incorporada a la sentencia». Por todo ello, se mantienen ciertas y limitadas «especialidades» como la carta de nupcias (capitulaciones matrimoniales), las donaciones propter nupcias, deber de información patrimonial de los cónyuges, criterios de valoración del trabajo o respecto a la vivienda habitual de la familia persista o no el vínculo matrimonial o derecho de predetracción de ajuar doméstico.

En definitiva, en estos más de treinta años el Tribunal Constitucional, en lo que se refiere a la donación, ha afirmado no solo las diferencias entre el matrimonio y otras uniones estables; el derecho a contraer matrimonio (art. $32 \mathrm{CE}$ ) y a no contraerlo como derecho de libertad y de desarrollo de la personalidad; la igualdad entre los cónyuges a los que les confiere la capacidad para celebrar todo tipo de contratos, que se reconoce con el máximo rango normativo; declarado inconstitucional las discriminaciones en razón de matrimonio o de parentesco que no tuvieran justa justificación (Aranda, Sieira y Rastrollo, 2017) y, precisado el alcance, contenido y limitaciones de regulación del derecho foral respecto a la competencia estatal en virtud del art. $149 \mathrm{CE}$.

Con esta base, procedemos a analizar el derecho a la revocación de las donaciones entre cónyuges que reconoce el Tribunal Supremo para precisar, a la luz de la doctrina del Tribunal Constitucional, si el enfoque responde a los parámetros que hasta ahora ha mantenido el Tribunal Constitucional. 


\section{ALGUNAS CONSIDERACIONES PREVIAS EN TORNO A LA DONACIÓN}

\section{DISTINCIÓN ENTRE LOS ACTOS DE LIBERALIDAD DE USO Y LAS DONACIONES. LA DONACIÓN}

Antes de analizar con detalle la donación y centrarnos en la donación entre esposos, conviene realizar una primera distinción entre los actos de liberalidad y las donaciones, pues aunque parece comúnmente aceptado por la doctrina el concepto diferenciado entre actos de liberalidad de uso y las donaciones strictu sensu, la jurisprudencia no ha establecido unas pautas claras que permitan distinguir las donaciones reguladas en el art. 644 y ss. del Código Civil, y las habituales liberalidades o regalos de uso, problemática que ha puesto de relieve la doctrina (Zarraluqui Navarro, 2020: 2) ${ }^{1}$.

Siguiendo a Cobacho (2017: 1011) consideramos liberalidades de uso los regalos que se realizan con ocasión de festividades, bodas, conmemoraciones o incluso las limosnas, y que vienen impuestas por los usos sociales. La mayoría de los autores consultados refieren como característica definitoria de las liberalidades que suponen una módica cantidad, aunque las circunstancias y la situación económica de quien realiza la liberalidad será la que establezca qué puede ser considerado en cada caso módica cantidad, y que esta se realiza por requerimiento de los usos sociales.

Incidiendo en estas características definitorias, y tal como subraya con claridad la doctrina (De los Mozos y De los Mozos, 2000: 78), los regalos de uso son actos a título gratuito a los que por su obligatoriedad social y por su relativa modicidad no se les aplican las reglas de las donaciones. Parece, pues, que las dos notas que caracterizarían los actos de liberalidad son su obligatoriedad como consecuencia de los usos sociales, y su modicidad (Verdera Server, 2017: 863).

Desde esta perspectiva y sin un concepto jurisprudencial claro, los actos de liberalidad que no sean de módico precio o que no debieran su justificación a obligaciones o demandas sociales, entendemos que debieran ser considerados como donaciones srictu sensu. Es decir, son donación aquellos «regalos» que tuvieran un alto coste, o bien que no respondieran a usos sociales; la ambigüedad de la definición nos advierte posibles problemas que coincidirían con los que procedemos a tratar para las donaciones vigente el régimen de gananciales, especialmente en situaciones de crisis familiar.

\footnotetext{
Zarraluqui, en una acertada reflexión, sostiene que el día a día familiar es mucho más complejo de lo que pudiera parecer entre líneas, mientras no existen crisis matrimoniales no habrá problemas en establecer si es un regalo o una donación, pero, dado que las consecuencias jurídicas de tipificar la acción en uno u otro caso generan situaciones absolutamente diferentes, es necesario que la jurisprudencia establezca si los dos elementos que parecen definir a las liberalidades de uso - la modicidad del precio y los usos socialesson realmente definitorias.
} 
Realizada una primera aproximación a la conceptualización de las liberalidades de uso que permite su distinción de la donación, ocupémonos ahora de esta última. El contrato de donación se regula en el Código Civil en el título II, en el cap. I, el art. 618 establece que: «La donación es un acto de liberalidad por el cual una persona dispone gratuitamente de una cosa en favor de otra, que la acepta» y que se perfecciona, conforme establece el art. 623 CC desde que el donante conoce la aceptación del donatario.

La donación supone, pues, una atribución patrimonial con animus donandi por la que el donante se empobrece a favor del donatario que se enriquece. Como señalaba ya el Tribunal Supremo en su sentencia de 20 de septiembre de 1986: «La donación es un negocio jurídico por el cual una persona, por voluntad propia, con ánimo de liberalidad (animus donandi) se empobrece en una parte de su patrimonio en beneficio de otra que se enriquece»; por lo tanto, debe existir la transmisión de la cosa o derecho para que se hable de donación.

En la actualidad (Gonzalez León, 2017:2) resulta pacífico admitir tanto por parte de la doctrina como por la jurisprudencia que la donación es un contrato en el que se necesita el concurso de la oferta y la aceptación; aunque en otros momentos se ha afirmado que se trata de un acto de adquisición de la propiedad a título gratuito (Navarro Mendizabal, 2019: 509)².

En el marco del derecho contractual europeo (Jerez Delgado, 2015: 24), el DCFR ${ }^{3}$, en el Libro IV "Contratos específicos y Derechos y Obligaciones derivados de ellos», en el Título H de la donación en IV. H.-1:101 (2), establece que: «Un "contrato de donación de bienes" es aquel en virtud del cual una parte, el donante, se obliga a transmitir la propiedad de determinados bienes a título gratuito a otra parte, el donatario, con el fin de beneficiar a este».

Teniendo en cuenta lo anterior parece lógico afirmar que estamos ante un contrato (acto jurídico bilateral) en el que se manifiesta el consentimiento por el concurso de la oferta y la aceptación, y que requiere el cumplimiento del resto de elementos propios de los contratos; quizá esta última afirmación puede resultar reiterativa, pero creemos que es necesaria la afirmación para comprender cuestiones que serán tratadas en los siguientes epígrafes.

La donación requeriría entonces de la capacidad general y la capacidad para disponer de los bienes objeto de la donación, lo que supone la libre disposición de los mismos; si bien la legislación, que tiende a ser protectora con el donante, suele evidenciar o procura generar una tensión entre no poner obstáculos al espíritu de liberalidad y frenar excesos indeseables del donante. Así el art. 634 del Código Civil

2 Es importante precisar que la calificación de la donación como acto, en vez de contrato, suele atribuirse a un error napoleónico al confundir contrato unilateral con acto jurídico.

3 El DCFR supone un instrumento sumamente útil para los tribunales (así mismo para la doctrina y los estudiantes) al interpretar el ordenamiento, pues permite con facilidad cumplir el mandato del art. 3.1 CC aproximando la interpretación a la realidad social del tiempo al que han de ser cumplidas. 
establece que la donación "podrá comprender todos los bienes presentes del donante o parte de ellos, con tal que este se reserve, en plena propiedad o en usufructo, lo necesario para vivir en un estado correspondiente a sus circunstancias».

En la donación, tal y como afirma la doctrina y ha puesto de manifiesto la jurisprudencia, la forma se configura como un requisito esencial para la validez de la donación, y esta es diferente en función de si el objeto de la donación es un bien mueble o inmueble, sus particularidades requieren una explicación que justifica el siguiente apartado.

\section{DISTINCIÓN ENTRE LA DONACIÓN DE BIEN MUEBLE Y BIEN INMUEBLE}

Como mencionábamos en el epígrafe previo, tanto en la donación de bienes muebles como en la donación de bienes inmuebles, la aceptación es esencial para la perfección del contrato de donación; el art. 630 CC establece con claridad que «el donatario debe, so pena de nulidad, aceptar la donación por sí, o por medio de persona autorizada con poder especial para el caso, con poder general y bastante».

Si se trata de donación de bienes muebles, el art. 632 CC establece que la donación podrá hacerse verbalmente o por escrito siendo objeto de donación manual todos los bienes de carácter corporal y los incorporales que sean aptos para ser puestos a disposición del donatario. Nuestro Código Civil a diferencia de otros (González León, 2017: 331), no establece límites por razón de cuantía o cosa donada, aunque como hemos tratado en el epígrafe anterior, la cuantía constituirá una cuestión esencial en las donaciones entre esposos para el supuesto en que tengamos que distinguir entre donación o liberalidades de uso, al menos hasta que la jurisprudencia clarifique ambos supuestos.

El Código Civil establece una distinción respecto al requisito de forma según sea bien mueble o inmueble; para que la forma se entienda cumplida en la donación de bienes muebles, la donación puede ser verbal o manual, sin que sea necesario el cumplimiento de forma diferente, bien sea por escrito o por cualquier otro modo. Ahora bien, la doctrina conviene que en este caso - donación de bienes muebles-, además de la coincidencia de la manifestación del donante de donar la cosa, debe producirse la aceptación simultánea del donatario mediante la entrega simultánea de la cosa, que debe entenderse como el hecho de ponerla a disposición del donatario. La puesta a disposición, es decir, la entrega, se entiende desde su conceptualización como contrato real, pues de ese modo se produce la perfección, que es a la vez prueba de la voluntad de donar. En caso contrario, cuando no mediase la puesta inmediata a disposición, tal y como dispone el art. $632 \mathrm{CC}$, se requerirá, al menos así lo ha venido interpretando la jurisprudencia, efectuar la donación por escrito para que conste tanto la voluntad de donar como la aceptación.

En esta línea el DCFR (Jerez Delgado, 2015: 298), en el Libro 4, título H, cap. 1, dispone cuál es el objeto de las donaciones muebles en IV. H.-1:103 cuando establece que el título - referido a las donaciones muebles - se aplicará a (a) contratos de donación de dinero; (b) de electricidad; (c) donación de valores 
mobiliarios, títulos, valores y efectos del comercio; (d) los contratos de donación de otras formas de bienes intangibles, incluidos los derechos al cumplimiento de obligaciones, derechos de propiedad industrial e intelectual y otros derechos transmisibles; (e) los contratos que concedan gratuitamente el acceso a información o datos, incluidos programas informáticos y bases de datos. Excluyendo expresamente que no será de aplicación (2) a los contratos de donación de bienes inmuebles o de derechos sobre bienes inmuebles.

El DCFR parece mantener entonces los requisitos de forma enunciados en los principios de nuestro Código Civil cuando en sostiene IV. H.-2:101 que, como requisito de formalización: «El contrato de donación de bienes - muebles - no será válido salvo que el compromiso del donante se contenga en una forma textual en un soporte duradero y sea firmado por el donante. A este respecto, no será suficiente una firma electrónica que no sea una firma avanzada en el sentido del apartado (4) del Artículo 1:107 («Firma» y expresiones similares) del Título I». Ahora bien, en IV. H.-2:102: establece las excepciones a los requisitos de forma, cuando proclama que no se aplicarán: "(a) en caso de entrega inmediata de los bienes al donatario o acto equivalente de dicha entrega, con independencia de si se transmite el dominio; (b) si la donación es efectuada por un empresario; (c) si la obligación del donante se declara públicamente en la radio o televisión o es publicada en prensa y no es excesiva en atención a las circunstancias.

Con todo lo expuesto queda claro, tanto en el marco de la legislación nacional como en el marco común de referencia europeo, que el animus donandi no se presume, por ello es esencial que en la donación verbal, la entrega de la cosa vaya unida a la voluntad y capacidad de disponer y de aceptar de las partes, siendo necesario que conste de un modo u otro la intención del donante y del donatario en el momento de entrega de la cosa. Como señala Albadalejo y Díaz Alabart. las voluntades de donante y donatario pueden expresarse de múltiples formas "por señas o gestos suficientemente significativos; por escrito sin firmar, que las partes digan asumir; por escrito con o sin firma, una parte, y con la conformidad no escrita de la otra. Con tal de que en cualquiera de estos casos haya entrega, vale la donación».

Como podemos constatar, en la donación, ya sea de bien mueble o de bien inmueble se exige la concurrencia ineludible de una serie de requisitos entre los que se encuentra el relativo a la aceptación del donatario, recogido de forma explícita en nuestro Código Civil en los arts. 618, 623, 629, 630, 632, 633, exigencia mantenida también por la jurisprudencia con criterio constante; en referencia a la forma, la jurisprudencia se inclina, con la intención evitar cualquier género de incertidumbre, que se haga constar de forma expresa la voluntad de donar y la aceptación, aunque es cierto que también confiere valor a la aceptación tácita, siempre y cuando se desprenda su existencia de actos inequívocos y concluyentes a fin de que el donante no tenga ninguna duda sobre su manifestación. 
La donación de cosa inmueble requiere, en lo relativo a la forma, mayor solemnidad para perfeccionar su validez y eficacia. Como establecía la sentencia del Tribunal Supremo de 13 de noviembre de 1999:

La solemnidad del negocio jurídico de la donación requiere para su validez y eficacia de la concurrencia ineludible de una serie de requisitos, entre los que se encuentra el relativo a la aceptación del donatario, que se encuentra recogido de manera explícita en los artículos 618, 623, 629, 630, 632 y 633 del Código Civil, cuyo requisito es también exigencia de una constante doctrina jurisprudencial, la cual se inclina por la necesidad y conveniencia de que el mismo se haga constar de modo expreso para evitar cualquier género de incertidumbre al respecto, pero, también, confiere valor a la aceptación tácita, siempre y cuando se desprenda su existencia de actos inequívocos y concluyentes a fin de que el donante no tenga ninguna duda sobre la manifestación.

Además, el art. 633 del Código Civil establece que, para que sea válida la donación de cosa inmueble, esta habrá de hacerse en escritura pública, expresándose en ella individualmente los bienes donados y el valor de las cargas que deba satisfacer el donatario. Vale por todas la sentencia del Tribunal Supremo de 24 de junio de 1988 siendo criterio constante y mantenido hasta la fecha, que ya estableció que "la ausencia de esta exigencia (formalización en escritura pública) comporta su nulidad absoluta por falta de uno de los requisitos esenciales para su existencia».

\section{LAS DONACIONES ENTRE ESPOSOS}

En los epígrafes previos nos hemos ocupado de distinguir entre las liberalidades de uso y las donaciones y entre las donaciones de bienes muebles e inmuebles, sentados los principios generales en ambos casos procedemos a profundizar en las cuestiones objeto de este artículo, que se centra en determinar si en las donaciones entre esposos existen diferencias sustanciales respecto a las donaciones efectuadas entre sujetos a los que no une un vínculo matrimonial, para después proceder a estudiar si existe alguna diferencia en las donaciones dependiendo del régimen económico por el que hayan optado los cónyuges.

\section{BREVE ANÁLISIS HISTÓRICO DE LA DONACIÓN ENTRE ESPOSOS}

La donación entre esposos ha resultado a lo largo de la historia un tema controvertido y generalmente en el ámbito nacional la legislación ha venido a prohibir la donación entre esposos. El origen y fundamento de la prohibición de donación entre los esposos (Andrés Santos, 2001: 317-396) ha sido estudiada de modo continuado por la doctrina romanista que ha afirmado 
que por el carácter poliédrico de la institución matrimonial (Buigues Oliver, 2017: 101), las relaciones patrimoniales entre los cónyuges son uno de los aspectos del matrimonio que presenta una gran variedad de posibilidades de estudio y regulación.

Las razones que han venido justificando la prohibición de donación entre cónyuges han sido puestas de manifiesto por la doctrina y responden a diferentes principios; unas aluden a la posibilidad de evitar las actuaciones de los cónyuges en fraude de acreedores; otras explican la prohibición desde el análisis de la capacidad jurídico-contractual de la mujer casada, en un momento histórico en que dada su sumisión al poder marital no podía disponer de un patrimonio propio (Buigues Oliver, 2014: 103); o bien al temor de que mediase la influencia de la voluntad de uno sobre la del otro; incluso por la posibilidad de que amparasen actuaciones fraudulentas hacia la legítima de los hijos o simplemente debido a la filosofía en extremo patriarcal predominante, lo cierto es que el Código Civil, siguiendo antecedentes enraizados en el propio derecho romano, hasta 1981, declara la nulidad de las donaciones entre cónyuges.

El proyecto de Código Civil de 1851, en su art. 1259, establecía de modo claro que: «La donación de un cónyuge a otro durante el matrimonio será nula. No se comprenden en esta regla los regalos módicos que los cónyuges se hagan en ocasiones de regocijo para la familia». En la misma línea, el Código Civil de 1889, en su art. 1334 II CC, establecía: «Será nula toda donación entre los cónyuges durante el matrimonio. No se incluyen en esta regla los regalos módicos que los cónyuges se hagan en ocasiones de regocijo para la familia», lo que suponía la absoluta prohibición de la donación entre cónyuges, salvo en el caso de que se tratasen de regalos módicos que los cónyuges se hagan en ocasiones especiales. Es decir, las donaciones se prohibían y se admitían las liberalidades de uso.

Con la llegada a España de la transición primero y la democracia después, se producen reformas jurídicas de gran calado que entre otras cuestiones afectan principalmente al estatus de la mujer y a su posición en el ordenamiento jurídico. El preámbulo de la Ley 14/1975 de 2 de mayo proclama un primer cambio cuando establece:

Una de las corrientes de opinión fuertemente sentidas en nuestros días en el ámbito del derecho privado, reflejo de auténticas necesidades de carácter apremiante, es la que incide sobre la situación jurídica de la mujer casada, que sufre limitaciones en su capacidad de obrar que, si en otros tiempos pudieron tener alguna explicación, en la actualidad la han perdido. Por lo demás, las normas en que tales limitaciones se contienen no pasan de tener una efectividad predominantemente formal, creadora de trabas en la vida jurídica, sin la contrapartida de una seria protección de los intereses de orden familiar.

En este sentido, el mismo preámbulo de la citada ley se proclama que: 
Base esencial de la nueva ordenación es la de que el matrimonio no tiene un sentido restrictivo respecto a la capacidad de obrar de los cónyuges. En consecuencia, ninguno de ellos ostenta una representación legal del otro, siendo posible únicamente la representación derivada de la voluntad. Corolario obligado es también que cada uno de los consortes puede realizar los actos jurídicos y ejercitar los derechos que le corresponden con carácter privativo o exclusivo.

Y se elimina también el vejatorio apartado tercero - en esos términos se establece el propio preámbulo_ _ del 1263, que asimilaba a la mujer a quienes física y psíquicamente carecen de los presupuestos normales de la capacidad.

El 8 y el 14 de febrero de 1977, las innovadoras resoluciones - considerando la perspectiva de la época- de la entonces denominada Dirección General de los Registros y del Notariado declararon la plena autonomía de ambos cónyuges para efectuar indistintamente actos de administración del patrimonio ganancial, y reconocían la capacidad para efectuar por sí solos adquisiciones de bienes para el mismo (Maldonado Ramos, 2020: 90). En concordancia con la evolución de las disposiciones, la Ley 11/1981 de 13 de mayo modifica el Código Civil dando una nueva redacción al art. 1323, permitiendo la celebración de todo tipo de contratos entre esposos: «El marido y la mujer podrán transmitirse por cualquier título bienes y derechos y celebrar entre sí toda clase de contratos». Los principios que gobernaban a la familia y que estaban recogidos en el Código Civil de 1889 fueron sometidos a una profunda revisión tras la entrada en vigor de la Constitución y el Derecho de familia desde aquel momento sufrió una absoluta transformación (Roca Trias,2018:1216).

Así pues, en 2021 podemos afirmar que el principio de igualdad entre los cónyuges está plenamente aceptado y que este se asienta sobre la afirmación de que ambos tienen igual capacidad para decidir la celebración de contratos entre ellos y, en el caso que nos ocupa, también la realización de donaciones sin que quepa discriminación en razón del matrimonio conforme al art. 14 de nuestra Constitución.

Es evidente, pues, que, a estas alturas, la licitud de la donación entre esposos no se pone en cuestión, siendo reafirmada con el contenido del art. 1323 del Código Civil que contempla la posibilidad de que los cónyuges se transmitan por cualquier título, bienes y derechos y celebren toda clase de contratos. Así también se afirma en la sentencia del Tribunal supremo de 27 de mayo 2019 cuando establece que:

Dada la amplitud con que el artículo 1323 CC admite la libertad de pactos y contratos entre los cónyuges, son posibles acuerdos por los que se atribuya carácter ganancial a bienes privativos de uno de ellos (por ejemplo, por haber sido adquiridos antes de la sociedad o adquiridos a título gratuito constante la sociedad de gananciales). 


\section{ELEMENTOS DE LA DONACIÓN ENTRE ESPOSOS}

Con la intención de establecer si aun a pesar de no estar prohibida la donación entre esposos, existe alguna peculiaridad propia al estatus matrimonial, vamos a detenernos brevemente en analizar los elementos de la donación entre esposos.

Manteniendo el sentido argumental de los epígrafes previos podemos sostener que las donaciones entre los cónyuges son negocios jurídicos de derecho de familia y, en la actualidad, plenamente lícitos, regulados tanto por el art. 618 CC como por la redacción del art. 1323 CC. Es decir, el Código Civil no establece diferencias de regulación si la donación se produce entre esposos, en el seno familiar o entre agentes extraños al entorno familiar.

Excluimos de este análisis las donaciones que se realizan en razón del matrimonio, pues a tenor de lo dispuesto en el art. 1336 CC la delimitación de lo que debe entenderse por donación en razón de matrimonio resulta relativamente sencilla, son aquellas donaciones que se realizan a uno, otro, o a ambos contrayentes, antes de la celebración del matrimonio en consideración al matrimonio que va a tener lugar; es decir, la clave de este tipo de donaciones es que se realizan en consideración a un matrimonio futuro. Coincidimos con Verdera cuando indica que (Verdera Server, 2017:858)

[...] actualmente, el grado de particularización de las donaciones por razón del matrimonio, respecto al régimen general, resulta escaso y no parece justificar su mantenimiento como categoría autónoma. Parece más razonable reconducir la singularidad de las donaciones por razón del matrimonio a la previsión, en su caso, de alguna matización al régimen general, tratando de poner de manifiesto la concreta causalización de esta donación y su conexión con la celebración del matrimonio. En consecuencia, el régimen de las donaciones por razón del matrimonio debería, sensatamente, perder su autonomía y proyectar a la regulación general aquellas cuestiones que se estimaran imprescindibles a la vista de la causalización de la donación.

El Código Civil dispone una serie de pactos especiales en la donación, conviene pues analizar si existe alguna especialidad en el caso de que se produzcan entre esposos y que esta genere alguna discriminación. Como nos explica Navarro Mendizábal (2019: 517), en el Código Civil podemos distinguir cuatro situaciones específicas, la primera consiste en que el donante se reserve la facultad de disponer de alguno de los bienes donados o de alguna cantidad con cargo a ellos (art. 639 $\mathrm{CC})$; la segunda implica la posibilidad de que el donante done la propiedad a una persona y el usufruto a otra u otras (art. 640); la tercera es mencionada por el Código Civil (art. 642) y supone la imposición de una obligación de pago de deudas del donante, aunque conforme al art. 643 si nada se ha dicho, «solo responderá de ellas el donatario cuando la donación se haya hecho en fraude de los acreedores»; y por último se puede establecer una cláusula de reversión. El art. 641 CC permite revertir la donación en favor del donador cuando establece: «Podrá establecerse 
válidamente la reversión en favor de solo el donador para cualquier caso y circunstancias, pero no en favor de otras personas sino en los mismos casos y con iguales limitaciones que determina este Código para las sustituciones testamentarias» y que se regulan en los arts. 774-789 CC.

Regula también el art. 644 la acción de revocación en la donación, estableciendo situaciones concretas (que el donante tenga después de la donación, hijos, aunque sean póstumos o que resulte vivo el hijo del donante que este reputaba muerto cuando hizo la donación) que prescriben por el transcurso de cinco años contados desde que se tuvo noticia del nacimiento del último hijo o de la existencia del que se creía muerto. También podrá ser revocada la donación, a instancia del donante, por las causas de ingratitud que enumera el art. 468 CC.

Hasta aquí nada parece indicarnos que en la regulación del Código Civil exista una diferenciación del tratamiento jurídico de la donación entre cónyuges o entre extraños en lo que se refiere a los elementos del negocio jurídico, si bien nos ocuparemos en el siguiente epígrafe de analizar entonces si los efectos de la donación o el acto de revocación de la misma entre esposos son diferentes de la donación entre los que no lo son, y analizada esta cuestión, si existe diferencia entre esposos cuyo régimen económico sea ganancial o privativo; de existir una diferencia también analizaremos si esta tiene causa en una especial protección a la familia de conformidad con los preceptos constitucionales, o existe una vulneración del derecho a la igualdad con discriminación en razón de matrimonio o del régimen económico matrimonial.

\section{CLÁUSULAS DE REVERSIÓN Y EL DERECHO DE REEMBOLSO EN LA DONACIÓN, A LA LUZ DE LA JURISPRUDENCIA RECIENTE DEL TRIBUNAL SUPREMO. ESPECIALES CIRCUNSTANCIAS ENTRE LOS CÓNYUGES EN FUNCIÓN DEL RÉGIMEN ECONÓMICO}

\section{LA DONACIÓN ENTRE CÓNYUGES Y LOS REGÍMENES ECONÓMICO MATRIMONIALES}

De lo expuesto hasta ahora podemos afirmar sin temor a equivocarnos que, conforme a lo dispuesto en el Código Civil, no existen diferencias en el régimen jurídico dispuesto para las donaciones entre cónyuges o entre extraños. Ahora bien, ¿sucede lo mismo en el supuesto de que los cónyuges opten por un régimen económico de separación de bienes o de gananciales? ¿Ha mantenido este criterio la jurisprudencia del Tribunal Supremo?

Analicemos qué supone adoptar un régimen económico matrimonial u otro para poder valorar los efectos de la donación entre los esposos vigente el régimen de ganancialidad o de separación de bienes. El Código Civil establece que, a falta de capitulaciones matrimoniales, o cuando estas sean ineficaces, el régimen 
económico matrimonial será el de gananciales, se excluye de este supuesto las especiales condiciones de algunos regímenes forales. El art. 1344 del Código Civil define con claridad los efectos del régimen de la sociedad de gananciales y sostiene que mediante la sociedad de gananciales se hacen comunes para los cónyuges las ganancias o beneficios obtenidos indistintamente por cualquiera de ellos, que les serán atribuidos por mitad al disolverse aquella.

El art. 1347 CC establece los bienes que tienen consideración de gananciales y estos son: los obtenidos por el trabajo o la industria de cualquiera de los cónyuges; los frutos, rentas o intereses que produzcan tanto los bienes privativos como los gananciales; los adquiridos a título oneroso a costa del caudal común, bien se haga la adquisición para la comunidad, bien para uno solo de los esposos; los adquiridos por derecho de retracto de carácter ganancial, aun cuando lo fueran con fondos privativos, en cuyo caso la sociedad será deudora del cónyuge por el valor satisfecho y las empresas y establecimientos fundados durante la vigencia de la sociedad por uno cualquiera de los cónyuges a expensas de los bienes comunes. $\mathrm{Si}$ a la formación de la Empresa o establecimiento concurren capital privativo y capital común, se aplicará lo dispuesto en el art. 1.354: «Los bienes adquiridos mediante precio o contraprestación, en parte ganancial y en parte privativo, corresponderán proindiviso a la sociedad de gananciales y al cónyuge o cónyuges en proporción al valor de las aportaciones respectivas».

Así mismo el art. 1353 establece que, en caso de bienes donados o dejados en testamento a los cónyuges conjuntamente y sin especial designación de partes, constante la sociedad, se entenderán gananciales siempre que la liberalidad fuera aceptada por ambos y el donante o testador no hubiere dispuesto lo contrario. Presumimos que la donación en este caso, para ser válida, requerirá de los elementos formales que analizábamos en los párrafos precedentes.

Conforme a lo expuesto mantenemos que la regulación del Código Civil establece la ganancialidad para todos aquellos bienes que incrementen el patrimonio de la sociedad de gananciales desde el momento de contraer matrimonio o desde el momento de otorgar capitulaciones estableciendo el régimen económico de gananciales. Esta presunción de ganancialidad queda reflejada en el art. 1361, pues, mientras no se pruebe que pertenecen privativamente a uno de los cónyuges, se considera que son gananciales; el art. 1347 establece que ese carácter será también ganancial, incluso si los bienes son adquiridos con fondos privativos, y corresponderán pro indiviso a la sociedad de gananciales, aunque en el momento de la disolución de la sociedad de gananciales podrá respetarse la aportación privativa en el caso de la constitución de empresas y establecimientos fundados cuando concurran bienes privativos y gananciales.

En este sentido el Código Civil da cumplimiento a la especial protección que la Constitución impone a los poderes públicos en la defensa de los valores regulados en el art. 1.1 CE, y que en el caso de la familia se explicita en el art. 39.1 de la Constitución cuando establece que «los poderes públicos aseguran la protección social, económica y jurídica de la familia» y en el art. 39.2 CE cuando se proclama el deber de asegurar la protección de los hijos. Sobre la protección social y económica 
de la familia que el art. 39.1 CE impone a los poderes públicos se ha pronunciado el Tribunal Constitucional en una jurisprudencia constante según la cual no se exige que dicha protección se dispense a través de medidas de una determinada naturaleza o, más concretamente, a través de un sistema tributario concreto, como tampoco demanda que se adopten medidas fiscales de una determinada intensidad, sin perjuicio de la legitimidad de medidas fiscales o penales que gozan de un trato diferenciado en la familia, pero sí supone una especial atención que permita no lesionar el ámbito familiar.

En lo que se refiere al régimen de separación de bienes, los patrimonios de los cónyuges permanecen completamente separados, y por ello pertenecerán a cada cónyuge los bienes que tuviese en el momento inicial del mismo y los que después adquiera por cualquier título, así como la administración, goce y libre disposición de tales bienes. No obstante, hay algunas limitaciones en la disposición del bien que afectan a la vida familiar en atención a la especial protección a la familia que proclama nuestra Constitución, es el caso del art. 1.320 del Código Civil que establece que, para vender la vivienda habitual y los muebles de uso ordinario de la familia, aunque pertenezcan a uno solo de los cónyuges, se requerirá el consentimiento de ambos o, en su caso, autorización judicial. Estos dos patrimonios se relacionan entre sí, salvo las disposiciones generales aplicables a todos los regímenes económico-matrimoniales, como los patrimonios de dos extraños.

Con ello a la pregunta que nos formulábamos sobre si la regulación de la donación, sus efectos o el acto de revocación de la misma entre esposos, es decir en aquellos que han contraído matrimonio, son diferentes, la respuesta en el caso que los cónyuges estén casados en el régimen de separación de bienes debe ser negativa, no existe diferenciación, pues salvo las obligaciones para con los hijos o cuestiones domésticas, los patrimonios se comportan igual que los que no han contraído matrimonio (Maldonado Ramos, 2020: 90) .

4 Es importante la precisión del autor cuando sostiene que es evidente que el criterio sentado por la Dirección General acerca del carácter especial de la Sociedad Legal de Gananciales en cuanto comunidad del tipo germánico se encuentra plenamente consolidado. Por otra parte, su incidencia en el tema de la validez de esas posibles donaciones entre esposos no parecía destinado a tener una gran transcendencia práctica, precisamente por las onerosas consecuencias tributarias de las mismas antes aludidas. Sin embargo, a partir del año 2006 el panorama fue cambiando radicalmente en el ámbito de ciertas comunidades autónomas, que, en uso de sus competencias al efecto, cedidas por el Estado central, han ido reduciendo la carga fiscal de las donaciones hasta convertirla en prácticamente inexistente. En tal contexto, no es infrecuente que parejas casadas, en uso de la facultad concedida por el art. 1342 del Código Civil, otorguen escrituras públicas efectuando este tipo de contratos entre sí, normalmente sobre sumas monetarias, sector donde el beneficio fiscal es total, al no concurrir otros supuestos impositivos que podrían añadir acarrear la incidencia de gravámenes añadidos (fundamentalmente, los casos de incrementos de patrimonio en el marco del IRPF o del aumento del valor de los terrenos de naturaleza urbana en los tributos municipales). Aunque en el texto del contrato no 
Ahora bien, ¿qué sucede en el caso de los cónyuges que optan por el régimen económico de gananciales? La voluntad de los cónyuges en el momento de optar por un régimen económico de ganancialidad es diferente a los que optan por establecer un régimen de separación de bienes, pues con su elección expresan su voluntad de formar un patrimonio común, el patrimonio de la sociedad de gananciales. En esta situación, ¿proceden los actos de liberalidad? ¿Dependerá de la procedencia del bien? ¿De la cuantía? ¿Todos los actos de liberalidad dentro del matrimonio son donaciones? ¿Es lo mismo realizar la donación al cónyuge a título personal o a la sociedad de gananciales? ¿Es posible realizar una donación entre cónyuges casados en el régimen de gananciales?

\section{DERECHO DE REEMBOLSO EN LA DONACIÓN ENTRE ESPOSOS EN RÉGIMEN DE GANANCIALES, A LA LUZ DE LA RECIENTE JURISPRUDENCIA DEL TRIBUNAL SUPREMO}

Hasta 2019 parecía comúnmente aceptada la presunción de ganancialidad de los bienes de los cónyuges casados en régimen de gananciales, tal y como contempla el art. 1361 CC, así lo afirma también el Tribunal Supremo en la sentencia casacional 295/2019 de 27 de mayo de 2019 cuando establece en su Fundamento de Derecho tercero 1 c) que el art. 1355 permite que los cónyuges atribuyan de común acuerdo carácter ganancial a un bien adquirido a título oneroso durante la vigencia de la sociedad de gananciales, con independencia de la procedencia de los fondos utilizados para la adquisición. El tribunal, en la citada sentencia, afirmaba que «frente a la atribución de ganancialidad realizada de forma voluntaria por los cónyuges, la prueba posterior del carácter privativo del dinero invertido sería irrelevante a efectos de alterar la naturaleza del bien,

se haga referencia alguna al carácter ganancial o no de las sumas donadas, siempre habrá que aplicar la presunción general en favor del mismo del art. 1361 del Código Civil, con lo cual la operación debería considerarse, precisamente, como un supuesto de disposición de un activo común en favor de uno solo de los cónyuges, lo cual le haría recaer en la aplicación de la doctrina al respecto antes reseñada. La solución ha llegado desde el propio Tribunal Supremo, pero en esta ocasión no precisamente de la Sala de lo Civil, sino de la Tercera, al examinar el tratamiento fiscal de las donaciones efectuadas por ambos cónyuges. La misma considera que en tal caso hay que estimar la existencia de dos actos independientes, uno por cada disponente, y no de uno solo conjunto de ambos. Así lo tiene declarado, entre otras, en las sentencias de 22 de junio y 22 de noviembre de 2002, y en la de 18 de febrero de 2009. Esta última estudia la reforma del Reglamento del Impuesto de Sucesiones y Donaciones de 1991, el cual, en consonancia con esa configuración globalizadora del patrimonio ganancial que se desprende de las sentencias y resoluciones reseñadas anteriormente, estableció la regla de que las disposiciones a título gratuito de bienes comunes efectuadas por ambos cónyuges debían considerarse como una sola donación. Sometido el estudio de la legalidad del precepto al Tribunal Supremo, la sentencia citada emitió un dictamen negativo, derogándolo. 
que ha quedado fijada por la declaración de voluntad de los cónyuges», si bien en el apartado d) del mismo Fundamento de Derecho 1 sostiene, en referencia a las donaciones realizadas por uno de los cónyuges casado en régimen de ganancialidad, con esta sentencia es ya criterio jurisprudencial al ser la tercera sentencia que se dicta en el mismo sentido - STS 498/2017 de 13 de septiembre; STS 415/2019 de 11 de julio y esta que citamos 295/2019 de 27 de mayo- que «la prueba del carácter privativo del dinero (que, frente a la presunción de ganancialidad del art. 1361 CC incumbe a quien lo alegue) puede ser determinante del derecho de reembolso del aportante (art. 1358)», precisando que "El derecho de reembolso procede, por aplicación del art. 1358, aunque no se hubiera hecho reserva alguna en el momento de la adquisición».

El criterio jurisprudencial de la Sentencia 295/2019 de 27 de mayo del Tribunal Supremo introduce dos importantes aclaraciones, que afectan únicamente a las donaciones efectuadas entre esposos casados en régimen de gananciales, que resulta trascendente, esencial en este artículo, precisar y comentar.

Por un lado sostiene que no es necesario que el adquirente de un bien realice ningún tipo de reserva sobre un potencial derecho de reembolso de su dinero privativo, pues seguirá conservando el derecho de reclamación en el futuro (sin efectuar reserva y por tiempo indefinido) si decide liquidar la sociedad de gananciales. De otro, que la presunción de ganancialidad de los bienes exige la voluntad común de los cónyuges, recayendo la carga de la prueba en quien sostiene la ganancialidad del bien que no se justifica, si la procedencia del bien es privativo, en la manifestación de voluntad registral; en definitiva, con el reciente criterio jurisprudencial se pone en cuestión la presunción de ganancialidad en los patrimonios de los cónyuges casados en gananciales, cuando se prueba que la procedencia del bien con el que se adquiere es privativo.

Más complejo es si cabe la cuestión en la donación de bienes inmuebles entre esposos casados en régimen de gananciales, pues ya no bastará con la aceptación que conlleva la disposición de la cosa, las sentencias reconocen que cabe ejercitar la acción de reembolso sin haber realizado la reserva que regula el Código Civil en cualquier momento cuando el bien que fue donado proceda de capital privado.

En este caso, la donación entre esposos casados en régimen de gananciales permite ejercitar la acción de reembolso en supuestos que no serían válidos en cualquier otra donación, provocando lo que podríamos denominar como «donación simulada» si con el paso del tiempo se decidiera ejercitar el derecho de reembolso. Creemos que la donación debería tener los mismos efectos y requisitos independientemente del estado civil o del régimen económico matrimonial por el que se opte, lo contrario sería dar validez a una discriminación.

En definitiva, el Tribunal Supremo, en la Sentencia 295/2019 de 27 de mayo de 2019 considera que son gananciales los bienes adquiridos conjuntamente por los esposos, cumpliendo los requisitos formales, cuando consta la voluntad de ambos de atribuir carácter ganancial al bien adquirido, pero, en tal 
caso, si se prueba que para la adquisición se han empleado fondos privativos, el cónyuge titular del bien tiene derecho a que se le reintegre el importe actualizado, aunque no hiciera reserva, en el momento de la adquisición, sobre la procedencia del dinero ni sobre su derecho de reembolso. Establece además que la declaración de un solo cónyuge de que adquiere para la sociedad o de que adquiere con carácter ganancial, incluso con la aceptación del otro cónyuge (o con la disposición del bien mueble entendemos, pues el objeto de las sentencias citadas eran bienes inmuebles) no es suficiente para que el bien tenga ese carácter, de modo que, si uno de los cónyuges prueba el carácter privativo del dinero empleado para la adquisición del bien, sobre este cabrá el derecho de reembolso sin necesidad de que se haya efectuado pacto previo o se hubiese advertido de la existencia del derecho e independientemente del tiempo transcurrido desde la llamémosla «simulada donación» o, cuanto menos, no firme.

En el mismo sentido que la sentencia citada, se ha pronunciado el Tribunal Supremo en la Sentencia 415/ 2019 de 11 de julio de 2019, que, de forma más escueta, en su Fundamento de Derecho primero establece que: «La cuestión jurídica planteada se reduce a determinar si, no obstante el carácter de ganancialidad del bien, por haberlo manifestado así expresamente ambos cónyuges en el momento de la adquisición, conserva el cónyuge que ha aportado dinero privativo para su adquisición un derecho de crédito frente a la sociedad de gananciales por el importe actualizado de la cantidad correspondiente», suponiendo entonces que la sociedad de gananciales es deudora del cónyuge que dio «apariencia» de donación y ello aun cuando entendemos que esta, en el momento de efectuarse, cumplía con todos los requisitos enunciados en los epígrafes previos y exigidos a la donación.

En resumen, la nueva interpretación del Tribunal Supremo, ya jurisprudencia, viene a establecer que, aun cuando el bien sea ganancial y se haya integrado en la sociedad de gananciales, el derecho de reembolso existirá siempre que pueda probarse que el origen del bien era privativo. La sentencia no establece en su interpretación plazo alguno, ni límite de bienes, ni conceptualiza el derecho de reembolso y ello aun cuando el derecho siempre reconoce y regula la posibilidad entre los esposos, en acto público o escritura pública, de formular reserva, manifestación o condición en la donación o acto de liberalidad; el propio art. 1354 permite la asignación de cuotas proindiviso conforme a la procedencia de aportación como bien privativo o para la sociedad de gananciales.

La citada interpretación jurisprudencial permite, pues, alterar la voluntad de liberalidad o donación en los bienes muebles cuando exista régimen de gananciales, siempre que el origen del bien sea privativo, quebrantando el principio de seguridad jurídica y alterando los elementos de los negocios jurídicos entre esposos, vulnerando la presunción de ganancialidad del Código Civil y rompiendo la especial protección a la familia que reconoce la Constitución. A nuestro juicio, con tal interpretación provoca una desigualdad ante la ley en razón de matrimonio con base en el régimen económico de gananciales, pues en ningún otro 
supuesto se permite ejercer el derecho de reembolso en las mismas condiciones que plantea la sentencia.

Desde esta perspectiva podemos formularnos la pregunta de otro modo: ¿podría ejercitarse ese derecho de reembolso en cualquier otra donación que no fuera entre esposos casados en régimen de gananciales toda vez que se han cumplido los requisitos que establece el Código Civil para las donaciones?

Conforme a la interpretación en aplicación de los arts. del Código Civil de las sentencias citadas y dictadas por el Tribunal Supremo, los actos de liberalidad, que evidentemente pueden afectar incluso a los regalos entre esposos, o cualquier donación de bienes muebles, puede ser revocada a través del derecho de reembolso, siempre que se pueda probar que el origen del bien con el que adquiere el objeto de liberalidad o sobre el que aplica el animus donandi era privativo conforme a la enumeración que realiza el art. 1346 del Código Civil, lo que supone añadir, en situaciones de crisis familiar, mayor tensión en la liquidación de la sociedad de gananciales.

En este caso, la voluntad con animus donandi manifestado en el acto de la entrega de la cosa en el acto de liberalidad o donación y la puesta a disposición no son considerados elementos esenciales del negocio jurídico, pudiendo ser revocado - aumentando los requisitos de revocación dispuestos en el Código Civil- para las donaciones entre esposos casados en régimen económico de gananciales por la facultar del donante o de quien realizó el acto de liberalidad a través de la exigencia del derecho de reembolso, aplicable siempre que se pruebe que el origen del bien fue privativo, y ello, además, sin plazo determinado ni requisito legal previo, sin considerar si, por ejemplo, la integración del bien en el patrimonio común de los esposos se ha utilizado para otras adquisiciones; nos preguntamos además si la acción de reclamación cabe ser ejercitada por herederos o solamente puede efectuarla el cónyuge donante, al fin y al cabo se trata de una acción de reclamación de cantidad con la obligación además de entregar las cuantías actualizadas.

Para dar respuesta a las preguntas formuladas, repasemos algunas cuestiones con el fin de analizar la importancia de la voluntad en la donación entre esposos casados en régimen de gananciales y determinar si quizá las diferencias tienen su razón en elementos esenciales diferenciales.

La doctrina distingue en los elementos de los negocios jurídicos entre elementos esenciales y accidentales. Entre los primeros se comprenden: la declaración de voluntad, el objeto, la causa y, en algunos negocios, la forma. Entre los segundos se incluyen figuras como la condición, el término o el modo. Por razones evidentes, nos centraremos en el análisis de la declaración de voluntad, pues el resto de cuestiones relativas a la donación ya han sido tratadas en los párrafos previos.

En el origen de todo negocio debe existir un acto de voluntad que supone la libre decisión de una persona de asumir determinados efectos, que el derecho en su caso valora y ampara. En el ámbito contractual se exige la voluntad concorde de dos o más personas o el consentimiento. Si extrapolamos estas afirmaciones a la donación 
entendemos que la voluntad en la donación supone la libre decisión de una persona de aceptar un empobrecimiento en su patrimonio. Ahora bien, conforme a las sentencias dictadas por el Tribunal Supremo en los supuestos analizados, la voluntad no supondría un elemento esencial del negocio jurídico de la donación, al menos entre esposos casados en régimen de gananciales, o quizá se da cabida a una simulación, si el origen del bien con el que se produce la donación o el acto de liberalidad es privativo, pues la libre decisión y el efecto de empobrecimiento no se produciría al poder ejercitar en cualquier momento el derecho de reembolso.

Ante esta circunstancia nos planteamos: ¿cómo es posible probar entonces la voluntad de un regalo? ¿Por el importe? ¿Por las acciones posteriores? ¿Por el testimonio de los esposos? ¿De una donación de bien mueble? Entendemos, como sostiene el Código Civil, que con la disposición de la cosa, o con la entrega de la misma pero ¿cómo probamos la voluntad de donar un bien mueble si solo se requiere para ejercitar la acción de reembolso probar el origen privativo del bien independientemente de las acciones posteriores?

En este sentido me inclino a pensar a la luz de la jurisprudencia sentada por el Tribunal Supremo en las sentencias dictadas en 2019, que la donación en un matrimonio que opte por un régimen económico de ganancialidad no es posible de forma definitiva, pues siempre es posible ejercitar la acción de reembolso en el momento de practicar la liquidación de gananciales y, si es posible, siempre es revocable cuando el origen del bien sea privativo, pues tampoco cabe donación dentro de la masa patrimonial común hasta el momento de proceder a la liquidación. Como establece el art. 1344 CC, los incrementos patrimoniales de los cónyuges en la sociedad de gananciales son gananciales.

A la luz de la Constitución y del propio Código Civil debería entenderse que, sin salvedad dispuesta en derecho al animus donandi o en la concreta acción de liberalidad, el bien se presume ganancial; así lo establece la sentencia de la Audiencia Provincial de Guadalajara (Sección Primera) en la sentencia dictada el 13 de marzo de 2017 y citada en la Sentencia del Tribunal Supremo 415/2019 de 11 de Julio que establece que:

En ausencia de declaración expresa de carácter privativo de la aportación alguna por parte del esposo, con omisión de anuncio concreto: de reserva o condición sobre las cantidades ingresadas, ni mención sobre el derecho de reembolso, es evidente la voluntad del consorte, de realizar a favor de la sociedad conyugal un desplazamiento patrimonial.

Indudablemente esta situación provoca situaciones de abuso y de inseguridad dentro del seno familiar, poniendo en cuestión la especial protección de la que debe gozar la familia conforme al mandato constitucional, en este caso singularizada en la masa común ganacial y por ello analizaremos la segunda de las cuestiones formulada, si este hecho supone una vulneración al principio de igualdad en razón de matrimonios casados en régimen de gananciales. 


\section{ANÁLISIS DESDE EL ENFOQUE CONSTITUCIONAL DE LA JURISPRUDENCIA DEL TRIBUNAL SUPREMO EN LAS DONACIONES ENTRE ESPOSOS CON RÉGIMEN ECONÓMICO DE GANANCIALES}

\section{EL PRINCIPIO DE IGUALDAD Y LA PROHIBICIÓN DE DISCRIMINACIÓN A LA LUZ DE LA JURISPRUDENCIA DEL TRIBUNAL CONSTITUCIONAL}

Como ha afirmado reiteradamente el Tribunal Constitucional y sostiene de nuevo en el FJ3 de la Sentencia 102/2020 de 21 de septiembre, el principio de igualdad «en la ley» impone al legislador el deber de dispensar un mismo tratamiento a quienes se encuentran en situaciones jurídicas iguales, con prohibición de toda desigualdad que, desde el punto de vista de la finalidad de la norma cuestionada, carezca de justificación objetiva y razonable o resulte desproporcionada en relación con dicha justificación.

Lo que prohíbe el principio de igualdad es, en suma, las desigualdades que resulten artificiosas o injustificadas por no venir fundadas en criterios objetivos y razonables, según criterios o juicios de valor generalmente aceptados; luego para que sea constitucionalmente lícita la diferencia de trato, las consecuencias jurídicas que se deriven de tal distinción deben ser proporcionadas a la finalidad perseguida, de suerte que se eviten resultados excesivamente gravosos o desmedidos ${ }^{5}$.

Es decir, el art. $14 \mathrm{CE}$, en su dimensión de igualdad en la ley, impide establecer distinciones entre supuestos de hecho que, desde el punto de vista de la finalidad perseguida por la norma, deban ser considerados iguales, de manera que su diferenciación sea tenida por arbitraria y discriminatoria.

En el FJ 4 de la Sentencia 91/2019 de 3 de julio, el Tribunal Constitucional viene a sintetizar la doctrina del tribunal sobre la igualdad, y sostiene que: «De acuerdo con nuestra doctrina sobre el art. $14 \mathrm{CE}$, dicho precepto constitucional acoge dos contenidos diferenciados: el derecho a la igualdad y las prohibiciones de discriminación». El propio tribunal se remite a la Sentencia 200/2001, de 4 de octubre, donde en su FJ 4 establece que el art. $14 \mathrm{CE}$ contiene en su primer inciso:

[...] una cláusula general de igualdad de todos los españoles ante la Ley, habiendo sido configurado este principio general de igualdad por una conocida doctrina constitucional, como un derecho subjetivo de los ciudadanos a obtener un trato igual, que obliga y limita a los poderes públicos a respetarlo y que exige que los supuestos de hecho iguales sean tratados idénticamente en sus consecuencias jurídicas y que, para

5 El mismo criterio muestra el Tribunal Constitucional en doctrina reiterada. Citamos las más relevantes SSTC 22/1981, de 2 de julio, FJ 3; 255/2004, de 23 de diciembre, FJ 4; 10/2005, de 20 de enero, FJ 5; 295/2006, de 11 de octubre, FJ 5; 83/2014, de 29 de mayo, FJ 7, y 167/2016, FJ 5. 
introducir diferencias entre ellos, tenga que existir una suficiente justificación de tal diferencia, que aparezca al mismo tiempo como fundada y razonable, de acuerdo con criterios y juicios de valor generalmente aceptados, y cuyas consecuencias no resulten, en todo caso, desproporcionadas.

El tribunal ya viene estableciendo en constante jurisprudencia que el art. 14 $\mathrm{CE}$ concreta la igualdad como valor superior del ordenamiento (art. $1 \mathrm{CE}$ ) en un verdadero derecho fundamental vinculante y directamente aplicable por jueces y tribunales, que no es simplemente instrumental a los demás derechos fundamentales, sino que adquiere un contenido propio. En un Estado social y democrático de derecho como el que establece nuestra Constitución, el derecho a la igualdad no consiste solamente en la exigencia formal de trato equitativo, sino en una exigencia material de tutela que garantice la efectividad sustancial de la igualdad entre los individuos y los grupos, y que remueva los obstáculos que impidan o dificulten su plenitud (art. 9.2 CE).

El Tribunal Constitucional, en la Sentencia 91/2019 de 3 de julio, recordando lo ya enunciado en las sentencias del propio Tribunal Constitucional 253/2004, de 22 de diciembre en su Fundamento Jurídico 5, la STC 61/2013 de 14 de marzo en su Fundamento Jurídico 4 a), y en la sentencia 156/2014 de 25 de septiembre en su Fundamento Jurídico 4, sintetiza los rasgos esenciales del derecho a la igualdad en los siguientes:

- No toda desigualdad de trato en la ley supone una infracción del art. 14 de la Constitución, sino que dicha infracción la produce solo aquella desigualdad que introduce una diferencia entre situaciones que pueden considerarse iguales y que carece de una justificación objetiva y razonable.

- El derecho a la igualdad exige que a iguales supuestos de hecho se apliquen iguales consecuencias jurídicas, debiendo considerarse iguales dos supuestos de hecho cuando la utilización o introducción de elementos diferenciadores sea arbitraria o carezca de fundamento racional.

- El derecho a la igualdad no prohíbe al legislador cualquier desigualdad de trato, sino solo aquellas desigualdades que resulten artificiosas o injustificadas por no venir fundadas en criterios objetivos suficientemente razonables de acuerdo con criterios o juicios de valor generalmente aceptados.

- Por último, para que la diferenciación resulte constitucionalmente lícita, no basta con que lo sea el fin que con ella se persigue, sino que es indispensable además que las consecuencias jurídicas que resultan de tal distinción sean adecuadas y proporcionadas a dicho fin, de manera que la relación entre la medida adoptada, el resultado que se produce y el fin pretendido por el legislador superen un juicio de proporcionalidad en sede constitucional, evitando resultados especialmente gravosos o desmedidos.

El Tribunal Constitucional, desde la STC 145/1991, de 1 de julio, afirma que la virtualidad del art. 14 no se concreta únicamente en la afirmación del 
principio de igualdad en los términos descritos, implica también la prohibición de discriminación en base a unos objetivos concretos, aunque la discriminación se permite en ciertos supuestos, como los enunciados en la Sentencia 75/1983 de 3 de agosto en su Fundamento Jurídico 6, no suponen en ningún caso ni privilegio ni su contrario, una discriminación, sino una enumeración general y concreta en términos abstractos. Lo que sí implica discriminación es plantear «determinadas diferencias históricamente muy arraigadas y que han situado, tanto por la acción de los poderes públicos como por la práctica social, a sectores de la población en posiciones, no solo desventajosas, sino contrarias a la dignidad de la persona».

La discriminación implica, como establece la Sentencia del Tribunal Constitucional 200/2001 en su Fundamento Jurídico 4, que,

a diferencia del derecho a la igualdad, que no postula ni como fin ni como medio la paridad y solo exige la razonabilidad de la diferencia normativa de trato, «las prohibiciones de discriminación contenidas en el art. $14 \mathrm{CE}$ implican un juicio de irrazonabilidad de la diferenciación establecida exconstitutione, que imponen como fin y generalmente como medio la parificación, de manera que solo pueden ser utilizadas excepcionalmente por el legislador como criterio de diferenciación jurídica, lo que implica la necesidad de usar en el juicio de legitimidad constitucional un canon mucho más estricto, así como un mayor rigor respecto a las exigencias materiales de proporcionalidad [...] y que «en tales supuestos, la carga de demostrar el carácter justificado de la diferenciación recae sobre quien asume la defensa de la misma y se torna aún más rigurosa en aquellos casos que quedan genéricamente dentro de la cláusula general de igualdad del art. $14 \mathrm{CE}$, al venir dado el factor diferencial por uno de los típicos que el art. $14 \mathrm{CE}$ concreta para vetar que en ellos pueda basarse la diferenciación, como ocurre con el sexo, la raza, la religión, el nacimiento y las opiniones.

Conviene constatar que el tribunal es sumamente preciso en lo que se refiere a las discriminaciones en razón de sexo, en las que incluye tanto la discriminación directa como la indirecta. La primera supone que la base de la discriminación es objetivamente el sexo de la persona, la segunda implica a aquellas medidas que, aun formuladas de manera neutra, perjudican a un porcentaje muy superior de mujeres que de hombres. En este tratamiento constitucional nuestro Tribunal Constitucional, tal y como se afirma en la Sentencia 91/2019 de 3 de julio en su Fundamento Jurídico 4c), "ha asumido el concepto elaborado por la jurisprudencia del Tribunal de Justicia de la Unión Europea, para referirse a aquellas medidas que, aunque formuladas de manera neutra, perjudican a un porcentaje muy superior de mujeres que de hombres: tales medidas están prohibidas salvo que estén justificadas por factores objetivos ajenos a cualquier discriminación por razón de sexo»" ${ }^{6}$.

6 La fundamentación la podemos encontrar también en las Sentencias del Tribunal Constitucional 22/1994, de 27 de enero, FJ 4; 240/1999, de 20 de diciembre, FJ 6, y 253/2004 FJ 7. 
En la actualidad, el concepto de discriminación indirecta por razón de sexo se encuentra expresamente recogido tanto en el derecho de la Unión Europea (art. 2.1 b) de la Directiva 2006/54/CE, del Parlamento Europeo y del Consejo, de 5 de julio de 2006, relativa a la aplicación del principio de igualdad de oportunidades e igualdad de trato entre hombres y mujeres en asuntos de empleo y ocupación, como en el ordenamiento interno nacional.

El art. 6 de la Ley Orgánica 3/2007, de 22 de marzo, para la igualdad efectiva de mujeres y hombres, incorpora el acervo comunitario sobre igualdad de sexos y establece la distinción sobre la discriminación directa e indirecta. Se considera discriminación directa por razón de sexo la situación en que se encuentra una persona que sea, haya sido o pudiera ser tratada, en atención a su sexo, de manera menos favorable que otra en situación comparable. Discriminación indirecta por razón de sexo se entiende como la situación en que una disposición, criterio o práctica aparentemente neutros pone a personas de un sexo en desventaja particular con respecto a personas del otro, salvo que dicha disposición, criterio o práctica puedan justificarse objetivamente en atención a una finalidad legítima y que los medios para alcanzar dicha finalidad sean necesarios y adecuados.

En cualquier caso, conviene considerar que la discriminación indirecta por razón de sexo no exige aportar como término de comparación la existencia de un trato más beneficioso atribuido única y exclusivamente a los varones o mujeres, sino que exista, en primer lugar, una norma —añadimos, nosotros, o su interpretación - que produzca efectos desfavorables para un grupo formado mayoritariamente, aunque no necesariamente de forma exclusiva, por mujeres. Y, en segundo lugar, se requiere que los poderes públicos no puedan probar que la norma - añadimos de nuevo, o su interpretación- que dispensa una diferencia de trato responde a una medida de política social, justificada por razones objetivas y ajenas a toda discriminación por razón de sexo. En definitiva, como afirma la Sentencia del Tribunal Constitucional 253/2004 en su FJ 7:

En estos supuestos, para que quepa considerar vulnerado el derecho y mandato antidiscriminatorio consagrado en el artículo $14 \mathrm{CE}$ debe producirse un tratamiento distinto y perjudicial de un grupo social formado de forma claramente mayoritario por mujeres, respecto de bienes relevantes y sin que exista justificación constitucional suficiente que pueda ser contemplada como posible límite al referido derecho.

\section{2 EXISTE A LA LUZ DE LA JURISPRUDENCIA DEL TRIBUNAL SUPREMO UN TRATAMIENTO QUE FALTA AL PRINCIPIO DE IGUAL EN LAS DONACIONES ENTRE ESPOSOS CASADOS EN RÉGIMEN DE GANANCIALES?}

Definido el derecho a la igualdad y la prohibición de discriminación de la jurisprudencia del Tribunal Constitucional, nos quedaría por abordar una 
última cuestión: ¿supone la reciente interpretación jurisprudencia del Tribunal Supremo en lo referente al derecho de reembolso de las donaciones realizadas entre cónyuges casados en régimen de gananciales una vulneración al principio de igualdad?

Ha quedado demostrado que el principio de igualdad constituye un verdadero derecho fundamental vinculante y directamente aplicable por jueces y tribunales, que no es simplemente instrumental a los demás derechos fundamentales, sino que adquiere un contenido propio y que este no precisa un trato igual en todos los supuestos, pero sí que en tales supuestos de desigualdad, la carga de demostrar el carácter justificado de la diferenciación recae sobre quien asume la defensa de la misma. Es, pues, necesaria una justificación razonable que guarde la debida proporcionalidad entre la medida adoptada, el resultado producido y la finalidad pretendida

Con la interpretación que se realiza en las sentencias, ya jurisprudencia del Tribunal Supremo respecto al derecho de reembolso, que justifica que, cuando se pruebe que el origen del bien donado es privativo, el tratamiento jurídico a la donación realizada entre cónyuges casados en régimen de gananciales es diferente al establecido en supuestos semejantes como es el caso de las parejas de hecho, o los cónyuges casados en régimen de separación de bienes, así como la donación misma realizada entre extraños, y ello sin justificación alguna, al menos hasta ahora se quiebra el principio de igualdad.

En ningún otro negocio jurídico es posible imaginar el mismo supuesto. Ante un hecho realizado en cumplimiento de la legislación que contempla el Código Civil, la jurisprudencia del Tribunal Supremo permite alterar los elementos del negocio jurídico, no solo en lo que se refiere a la voluntad del donante y el donatario, sino en el resto de elementos definitorios de la donación, permitiendo, en los casos en los que así sea, una especie de «donación simulada», pues si el origen del bien es privativo cabe ejercitar, en cualquier momento, independientemente del plazo de tiempo transcurrido y sin haber realizado reserva previa, el derecho de reembolso y que tal donación tenga los efectos de ¿̇nulidad? ¿anulabilidad? sin que tampoco se haya precisado qué ocurre si al ejercitar el derecho de reembolso, que provoca una disminución de la masa patrimonial común, se perjudica a terceros de buena fe. No solo pensamos en los hijos, también en cualquiera que haya efectuado un negocio jurídico con los esposos que, hasta que se ejercita el derecho de reembolso, actúan en la creencia de la efectividad de la donación.

La jurisprudencia del Tribunal no establece plazos de ejercicio del derecho, ni la existencia de la posibilidad de reservas, o asignación de cuotas, o manifestaciones... se permite que «donde digo digo, digo Diego». Primero realizo el regalo o la donación y, en situaciones de tensión en las que suele mediar divorcio, como en los hechos juzgados en las sentencias citadas, solicito el reembolso toda vez que pruebo que el bien es privativo.

Sin embargo, no solo creemos que supone una vulneración del derecho a la igualdad, quizá también puede suponer una discriminación en razón de 
sexo, pues, si tomamos como base la citada Sentencia del Tribunal Constitucional 91/2019, de 3 de julio, en su Fundamento Jurídico 4c) establece que el concepto de discriminación se refiere a «aquellas medidas que, aunque formuladas de manera neutra, perjudican a un porcentaje muy superior de mujeres que de hombres: tales medidas están prohibidas salvo que estén justificadas por factores objetivos ajenos a cualquier discriminación por razón de sexo».

Las desigualdades retributivas entre hombres y mujeres son un hecho, el informe de Eurostat ${ }^{7}$ revela que, a pesar de que progresivamente tiende a haber una cierta convergencia entre los salarios de hombres y mujeres, sigue habiendo una diferencia sustancial entre los ingresos medios de hombres y mujeres en la UE, un concepto conocido comúnmente como brecha salarial entre hombres y mujeres. Por término medio, en 2012 el salario de las mujeres fue un 16,4\% más bajo que el de los hombres en el conjunto de EU-28. Las diferencias más pequeñas entre la media de ingresos de hombres y mujeres se registraron en Eslovenia, Malta, Polonia, Italia, Luxemburgo y Rumanía (menos de un 10,0\%). Las mayores diferencias salariales entre hombres mayores se encontraron en Estonia (30,0\%), Austria $(23,4 \%)$, Alemania $(22,4 \%)$ y Chequia $(22,0 \%)$.

Así mismo el informe sostiene que hay diversos efectos que contribuyen a estas brechas salariales entre hombres y mujeres, como las diferencias en los índices de participación de la población activa, las diferencias en las profesiones y actividades que tienden a estar dominadas por la presencia de hombres y mujeres, las diferencias en el grado en que hombres y mujeres trabajan a tiempo parcial, así como las actitudes de los departamentos de personal en los organismos públicos y privados hacia el desarrollo de carreras profesionales y las excedencias o el permiso de maternidad. Entre los factores subyacentes que pueden explicar, al menos en parte, la brecha salarial entre hombres y mujeres, figuran la segregación sectorial y profesional, la educación y la formación, la sensibilización y la transparencia, así como la discriminación directa. La brecha salarial refleja asimismo otras desigualdades, en especial la parte, con frecuencia desproporcionada, de responsabilidades familiares que recae sobre las mujeres y las dificultades a la hora de conciliar el trabajo con la vida privada. Muchas mujeres trabajan a tiempo parcial o con contratos atípicos: si bien esto les permite seguir integradas en el mercado laboral mientras hacen frente a las responsabilidades familiares, también puede tener un impacto negativo en su nivel salarial, la evolución de su carrera, sus perspectivas de ascenso y sus pensiones la Unión Europea y el Gobierno Español tratan de limitar estas circunstancias aprobando normas concretas y generando acciones políticas que permitan ir disminuyendo hasta su desaparición esas brechas salariales entre hombres y mujeres.

Muestra de esta situación son los dos recientes reales decretos que ha aprobado el Gobierno: Real Decreto 901/2020, de 13 de octubre, por el que se regulan los planes de igualdad y su registro y se modifica el Real Decreto 713/2010, de 28 de

$\overline{7 \text { https://bit.ly/3DI6eLG }}$ 
mayo, sobre registro y depósito de convenios y acuerdos colectivos de trabajo; y el Real Decreto 902/2020, de 13 de octubre, de igualdad retributiva entre mujeres y hombres, ambos mantienen la pretensión de evitar las discriminación en base a las desigualdades retributivas entre hombres y mujeres.

En consecuencia y ante la falta de igualdad salarial, es también posible argumentar que en términos globales, las mujeres, como colectivo, disponen de un menor poder adquisitivo, por lo que en el caso de admitirse la interpretación del Tribunal Supremo, respecto a las donaciones realizadas entre esposos en régimen de gananciales, probablemente el colectivo en el que se produzcan resultados especialmente gravosos sean las mujeres que optaron por un régimen económico de gananciales en el momento de contraer matrimonio, pues en estos casos, a la luz de las estadísticas, la mujer realiza una aportación menor por su inferior salario.

Cuando un matrimonio decide casarse en régimen de ganancialidad, lo que está declarando es su voluntad, que pueden modificar en cualquier momento vigente el matrimonio, de formar un patrimonio común, el patrimonio de la sociedad de gananciales en el que en el momento de la disolución corresponderá a ambos cónyuges al 50\%. Pero en el caso de ejercitar el derecho de reembolso en las donaciones realizadas constante el matrimonio conforme a la jurisprudencia dictada por el Tribunal Supremo, al no producirse un empobrecimiento del donante, pues es posible ejercitar el derecho de reembolso en cualquier momento, siempre que sea posible probar que el origen del bien es privativo - la jurisprudencia hasta ahora no ha establecido límite de tiempo alguno para limitar el derecho reembolso a un plazo de tiempo- se produce un empobrecimiento de la sociedad de gananciales, perjudicando a la masa común de los esposos.

Con su interpretación, a nuestro juicio, la jurisprudencia del Tribunal Supremo pone en cuestión la especial protección a la familia que reconoce nuestro ordenamiento, permitiendo que uno de los cónyuges revierta a su patrimonio individual lo donado o lo aparentemente donado a la sociedad de gananciales en el momento de disolución de la misma, disminuyendo la masa patrimonial común, destinada principalmente a la asunción de las cargas familiares.

La Constitución impone a los poderes públicos en la defensa de los valores regulados en el art. 1.1 CE, y que en el caso de la familia se explicita en el art. 39.1 de la Constitución la obligación de asegurar la protección social, económica de la familia y, en el art. 39.2 específicamente, el deber de asegurar la protección de los hijos. Sobre la protección social y económica de la familia que el art. 39.1 CE impone a los poderes públicos se ha pronunciado el Tribunal Constitucional en jurisprudencia constante según la cual no se exige que dicha protección se dispense a través de medidas de una determinada naturaleza o, más concretamente, a través de un sistema tributario, como tampoco demanda que se adopten medidas fiscales de una determinada intensidad, sin perjuicio de la 
legitimidad de medidas fiscales o penales que gozan de un trato diferenciado en la familia, solo requiere que no exista un perjuicio.

Llegados a este punto, la interpretación jurisprudencial no solo supondría una vulneración del art. 14, o del 24 de la Constitución sin indefensión, pone en tela de juicio el propio estado de derecho consagrado en el art. 1.1 y en los principios regulados en el art. 9.3, por cuanto que la jurisprudencia del Tribunal Supremo en lo que se refiere a las donaciones y al derecho de reembolso elimina cualquier atisbo de predictibilidad, pues una donación, aun reuniendo los requisitos formales, deja de serlo probando la procedencia del caudal privativo de uno de los cónyuges independientemente de si las acciones posteriores del donante desde el momento de la donación manifestaban un animus donandi.

Como ha expresado el Tribunal Constitucional en su jurisprudencia, por todas la Sentencia 38/1981 de 20 de julio de 1981 (BOE 13 de agosto, núm. 193) que en el FJ 10 establece que el Estado de derecho es la:

suma de certeza y legalidad, jerarquía y publicidad normativa, irretroactividad de lo no favorable, interdicción de la arbitrariedad, pero que, si se agotara en la adición de estos principio, no hubiera precisado de ser formulada expresamente. La seguridad jurídica, es la suma de estos principios, equilibrada de tal suerte que permita promover en el orden jurídico, la justicia y la igualdad en la libertad.

La jurisprudencial del Tribunal Supremo en materia de donaciones entre esposos casados en régimen de gananciales cuestiona la seguridad jurídica y el principio de predictibilidad, pues la donación mantenida en el tiempo y en base a la cual pueden los esposos realizar acciones de disposición, puede revocarse al permitirse que si el bien del que procede es privativo se ejercite el derecho de reembolso y además actualizado.

La citada interpretación jurisprudencial del Tribunal Supremo permite en cualquier momento alterar la voluntad de liberalidad o donación en los bienes muebles cuando exista régimen de gananciales, siempre que el origen del bien sea privativo, quebrantando el principio de seguridad jurídica y alterando los elementos de los negocios jurídicos entre esposos, vulnerando la presunción de ganancialidad del Código Civil y rompiendo la especial protección a la familia que reconoce la Constitución. A nuestro juicio, con tal interpretación se provoca una desigualdad ante la ley, en razón de matrimonio con base en el régimen económico de gananciales.

\section{CONCLUSIONES}

Desde el año 2019 el criterio jurisprudencial de interpretación del derecho de reembolso en las donaciones entre esposos casados en régimen de gananciales 
se ha visto modificado, siendo admitido por el tribunal como jurisprudencia que, aunque el bien mantenga el carácter ganancial, por haberlo manifestado expresamente ambos cónyuges en el momento de la adquisición, si se prueba que el dinero con el que realizó la adquisición procedía de caudal privativo, se reconoce el derecho de reembolso, sin que sea necesario haber realizado acción de reserva previa a favor del cónyuge que realizó la aportación, y ello sin límite de tiempo o sin estar sujeto a un periodo concreto.

Analizando la situación desde un enfoque constitucional, y tal y como hemos ido justificando a lo largo del artículo, la jurisprudencia del Tribunal Supremo vulnera principios esenciales en el orden constitucional. En primer lugar se produce una vulneración del principio de igualdad regulado en el art. 14 de la Constitución que, como ha puesto de manifiesto en jurisprudencia reiterada el Tribunal Constitucional, constituye un verdadero derecho fundamental vinculante y directamente aplicable por jueces y tribunales, que no es simplemente instrumental a los demás derechos fundamentales, sino que adquiere un contenido propio y que este no precisa un trato igual en todos los supuestos, pero sí que en tales supuestos de desigualdad la carga de demostrar el carácter justificado de la diferenciación recae sobre quien asume la defensa de la misma. Es pues necesaria una justificación razonable que guarde la debida proporcionalidad entre la medida adoptada, el resultado producido y la finalidad pretendida, que no se produce en el caso de ejercitar el derecho de reembolso en las donaciones realizadas entre esposos casados en régimen de gananciales.

Analizando la jurisprudencia del Tribunal Supremo desde el enfoque constitucional, creemos, y así se ha puesto de relieve en este artículo, que no solo supone una infracción del principio de igualdad, sino que pone en cuestión el propio Estado de derecho, definido por el Tribunal Constitucional como la suma de certeza y legalidad, jerarquía y publicidad normativa, irretroactividad de lo no favorable, interdicción de la arbitrariedad, que se expresa de forma global en la seguridad jurídica, pues un negocio jurídico como la donación, que se perfecciona con todos sus elementos y los requisitos de aceptación y disposición puede ser «transformado" dejando sin efecto acciones previas por la voluntad de una de las partes con el único requisito de probar que la procedencia del bien era de caudal privativo. Dando lugar a una situación jurídica impensable en cualquier otro negocio jurídico, o entre sujetos que no constituyan parte de una unidad familiar.

En la misma línea, esta acción, como hemos intentado demostrar, creemos que puede suponer también una quiebra al principio de especial protección a la familia, que la Constitución impone a los poderes públicos en la defensa de los valores regulados en el art. 1.1 CE, y que en el caso de la familia se explicita en el art. 39.1 de la Constitución la obligación de asegurar la protección social, económica de la familia, y en el art. 39.2 específicamente el deber de asegurar la protección de los hijos. 


\section{Bibliografía}

Andrés Santos, F. J. (2000). En torno al origen y fundamento de la prohibición de donaciones entre cónyuges: una reconsideración crítica. Bullettino dell'Istituto di Diritto Romano "Vittorio Scialoja», 42, 317-396.

Aranda, E., Sieira, S. y Rastrollo, A. (2017). Comentarios al artículo 32 Constitución Española. Portal del Congreso de los Diputados. Disponible en: https://bit. ly/3I2vGiy.

Buigues Oliver, G. (2014). La posición juridica de la mujer en Roma. Presupuestos para un análisis de la capacidad negocial de la mujer. Madrid: Dykinson.

- (2017). La simulación de compraventa entre cónyuges encubriendo donación: un análisis de fuentes. Revista General de Derecho Romano, 28, 1-45.

Cobacho Gómez, A. J. (2017). Las liberalidades de uso. En A. M. Egusquiza, M. C. Pérez de Ontiveros y R. Bercovitz (dirs.). Tratado de las liberalidades (homenaje al profesor Enrique Rubio) (pp. 1105-1125). Cizur Menor: Aranzadi.

De los Mozos, J. L. (2000). La donación en el Código Civil a través de la jurisprudencia. Madrid: Dyckinson.

Egusquiza, M. y Verdera Server, R. (2017). Algunas preguntas (y pocas respuestas) en torno a las donaciones por razón de matrimonio. En A. M. Egusquiza, M. C. Pérez de Ontiveros y R. Bercovitz (Dirs.). Tratado de las liberalidades (homenaje al profesor Enrique Rubio) (pp. 857-880). Cizur Menor: Aranzadi.

González León, C. (2017). La donación de cosa mueble. En A. M. Egusquiza, M. C. Pérez de Ontiveros y R. Bercovitz (dirs.). Tratado de las liberalidades (homenaje al profesor Enrique Rubio) (pp. 325-355). Cizur Menor: Aranzadi.

Jerez Delgado, C. (2015). Principios, definiciones y reglas de un Derecho Civil Europeo: El marco común de referencia (DCFR). Madrid: Boletín Oficial del Estado.

Lacruz, J. L., Sancho Rebullida, F., Luna Serrano, A., Delgado Echevarría, J., Rivero Hernández, F. y Rams Albesa, J. (1999). Elementos del Derecho Civil, vol. 2. Madrid: Dykinson.

Maldonado Ramos, I. (2020). Las donaciones entre cónyuges y la naturaleza de la sociedad de gananciales. El notario del siglo XXI: revista del Colegio Notarial de Madrid, 91, 90-95. Disponible en: https://bit.ly/3vZwDCN.

Navarro Mendizábal, I. A. (2019). Derecho de Obligaciones y contratos. Pamplona: Thomson Reuters, Civitas.

Roca, E. y Díez-Picazo, G. (2018). La familia en el marco de la Constitución Española. En B. Pendas (dir.), E. González y R. Rubio (coords.). España Constitucional (1978-2018). Trayectoria y Perspectivas (pp. 1215-1223). Madrid: Centro de Estudios Políticos y Constitucionales.

Roger Vide, C. (2011). Las liberalidades de uso. Madrid: Reus.

Zarraluqui Navarro, L. (2020). Donación versus liberalidad dentro del matrimonio; la protección constitucional de la familia. Actualidad jurídica Aranzadi, 960, 7-7. Disponible en: https://bit.ly/3Ekk9s2. 


\section{Índice de sentencias citadas}

STS de 20 de septiembre de 1986.

STS de 24 de junio de 1988.

STC 209/1988 DE 10 de 10 de noviembre.

STC 45/1989 de 20 de febrero.

STC $184 / 1990$ de 15 de noviembre.

STC 121/1992 de 28 de septiembre.

STC 146/1994 de 12 de mayo.

STS de 13 de noviembre de 1999.

STC 47/2004 de 25 de marzo.

STC 21/2012 de 16 de febrero.

STC 198/2012 de 6 de noviembre.

STC 93/2013 de 23 de abril.

STC 60/2015 de 18 de marzo.

STC 82/2016 de 28 de abril.

STS 498/2017 de 13 de septiembre.

STC 55/2018 de 24 de mayo.

STC 69/29018 de 4 de junio.

TS 295/2019 de 27 de mayo de 2019.

STS 415/2019 de 11 de julio.

STC 102/2020 de 21 de septiembre.

STC 91/2019 de 3 de julio.

STC 200/2001, de 4 de octubre.

STC 91/2019 de 3 de julio.

STC 253/2004, de 22 de diciembre.

STC 61/2013 de 14 de marzo.

STC 156/2014 de 25 de septiembre.

STC 145/1991, de 1 de julio.

STC 75/1983 de 3 de agosto.

STC 253/2004 de 22 de diciembre.

STC 38/ 1981 de 20 de Julio de 1981 (BOE 13 de Agosto No 193). 